\title{
Umbrella review: Methodological review of reviews published in peer-reviewed journals with a substantial focus on vocational education and training research
}

\author{
Michael Gessler ${ }^{\star}$ and Christine Siemer \\ University of Bremen, Institute Technology and Education (ITB), \\ Am Fallturm 1, 28203 Bremen, Germany
}

Received: 25.09.2019, Accepted: 03.02.2020, Published: 29.04.2020

\begin{abstract}
Purpose: The growing public interest in vocational education and training (VET), most recently since the economic crisis of 2007/2008, has led to an exponential increase in articles with a vocational focus, underscoring the need for review studies for the purposes of systematic knowledge aggregation, clarification and interpretation. We assume that review studies follow the same minimum standards as other research methods: the review must be at least reproducible and thus the results verifiable or falsifiable. So far, however, the review methods used in VET research have not been investigated. Our purpose is to review the review procedures and methods used in published reviews of VET research to identify their current methodological quality.
\end{abstract}

Approach: To classify the review studies, we initially developed a conceptual framework to distinguish different types of reviews. We then developed a methodological framework to assess the review methods used. Overall, to accelerate the review process, our review of reviews (or umbrella review) followed the rapid review approach: we limited our search to reviews in English published between 2014 and 2019 in peer-reviewed journals with a substantial VET focus and indexed in Scopus and/or Web of Science. Therefore, we did not examine all existing reviews in the field of VET research. Rather, our specific focus was on a core sector of scientific research: peer-reviewed articles in curated databases. Furthermore, we concentrated on the review procedures and methods used, not on the content of the reviews.

${ }^{\star}$ Corresponding author: mgessler@uni-bremen.de 
Findings: We identified nine journals with a substantial VET focus, yielding a total of 1,283 published articles between 2014 and 2019, of which only 19 articles (1.48\%) were literature reviews. Of these 19 reviews, six were excluded from our umbrella review because of unclear methodological procedures. Based on the review typology we developed, five of the remaining 13 reviews were conceptual in nature, four were scoping reviews, three were evidence-oriented, and one was critical in nature. None of the reviews examined focused on meta-syntheses, research methods or meta-analyses. In total, this resulted in current review gaps with respect to theory generation (meta-synthesis), practice of theory elaboration and testing (methodological review) and the determination of overall effects across single studies (meta-analysis). Finally, our examination of the reviews showed that their scope was mostly clearly presented. However, with regard to the process steps data selection and data processing, only a few reviews fully met the requirements of the methodological framework.

Conclusion: Our review leads to four conclusions. 1) More systematic syntheses are needed because there is a substantial quantitative gap in review research. 2) In particular, there is a need for review studies with a focus on meta-synthesis, research methods and meta-analysis, as there is a current gap in these areas. 3) Reviews should be based on a review methodology with transparent and reproducible methods and verifiable or falsifiable results. The high number of subjective syntheses with unclear review procedures indicates that this mindset is not yet fully established in the field of VET research. 4) In the studies examined, there is a high degree of heterogeneity regarding to the accuracy and completeness of the methodological steps and data. The conceptual and methodological frameworks developed for the analysis can serve as guidelines for the conduct of reviews, and thus, the frameworks could contribute to the further development of the methodological basis of reviews.

Keywords: Literature review, umbrella review, review of reviews, typology, vocational education and training, VET

\section{Research problem and research question}

Since the financial crisis of 2007/2008, at the latest, vocational education and training (VET) has gained a high degree of attention, as it is often perceived as a solution to socioeconomic problems following financial crises, particularly the rise of youth unemployment. VET is also viewed as an instrument for increasing an economy's productivity, capacity for innovation and competitiveness (Chankseliani \& Anuar, 2019; Gessler, 2019; Salvà et al., 2019). 


\subsection{Increased research on vocational education and training}

This multifunctionality of VET has not only led to a high degree of attention but also to an exponential $\left(\mathrm{R}^{2}=0.9427\right)$ growth in the number of VET-related articles $(\mathrm{N}$ with vocation* in the title, cumulated until $2018=14,088$ ), which has resulted in the need for literature reviews. Literature reviews are "systematic syntheses of previous work around a particular topic" (Card, 2010, p. 725). The number of literature review articles ( $\mathrm{N}$ with vocation* and review in the title, cumulated until $2018=144$ ) has also grown exponentially to a similar extent $\left(\mathrm{R}^{2}=0.946\right)$, although there is a dearth of review syntheses (Figure 1$)$.

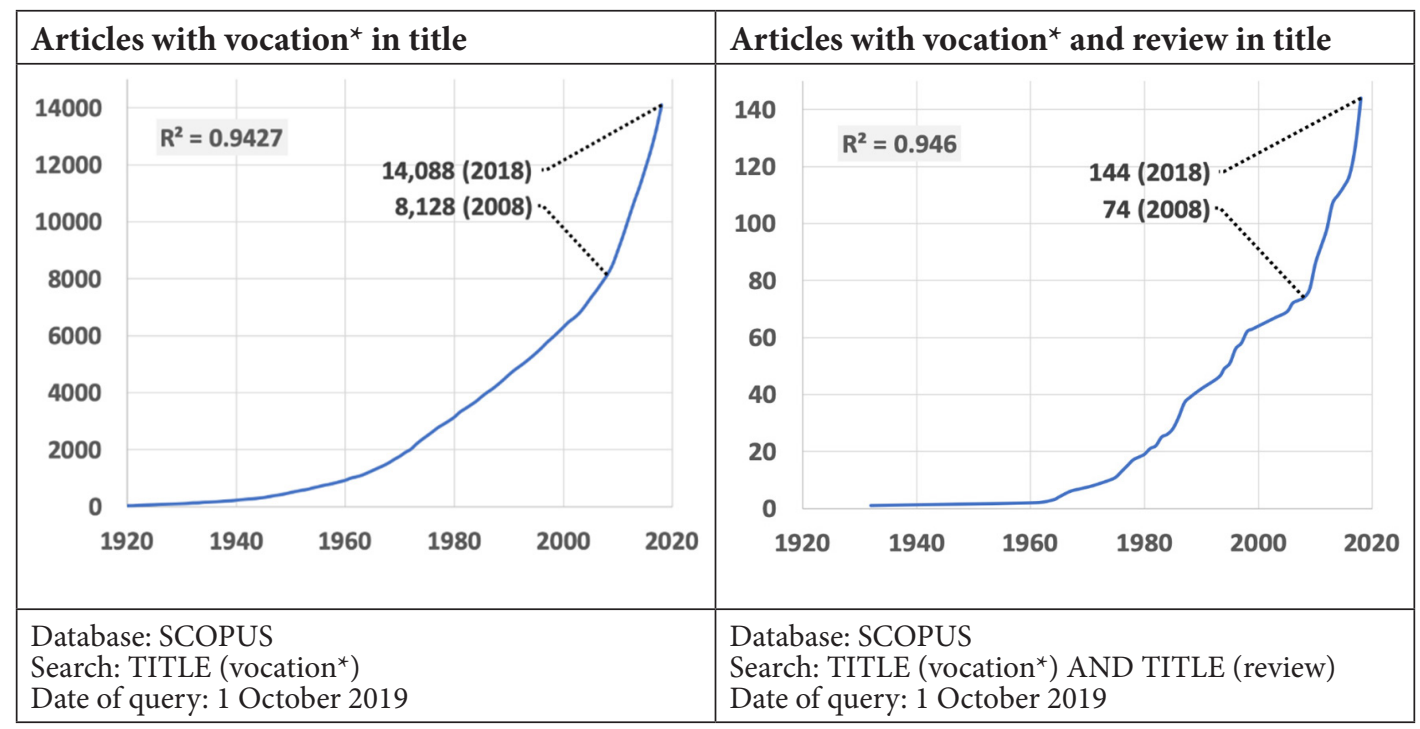

Figure 1: Cumulated VET-related articles and reviews up to 2018

The lack of systematic knowledge synthesis is obvious, but the methodological quality of the literature reviews is not evident. Is the existing review corpus small but excellent? We use the review of reviews or the umbrella review approach (Grant \& Booth, 2009) to assess the methodological quality of the existing reviews. Our overall research question is as follows: what is the methodological quality of reviews with a VET-related focus?

\subsection{Methodological quality of reviews: reproducibility}

In recent years, there has been evidence showing that "many science studies are not reproducible" (Sayre \& Riegelman, 2018, p. 2). The so-called reproducibility crisis sets the frame for the definition of methodological quality used here: review studies have to be at least repro- 
ducible. In this paper, we use the following definition: "Reproducibility refers to the ability of a researcher to duplicate the results of a prior study using the same materials and procedures as were used by the original investigator" (Bollen et al., 2015, p. 3). Reproducibility requires transparency, especially by "providing methodological details of research" (Bollen et al., 2015, p. 22). Applying the definition of Bollen et al., (2015), every literature review requires methodology and explicity as the minimum criteria to enable transparency and reproducibility (Figure 2).

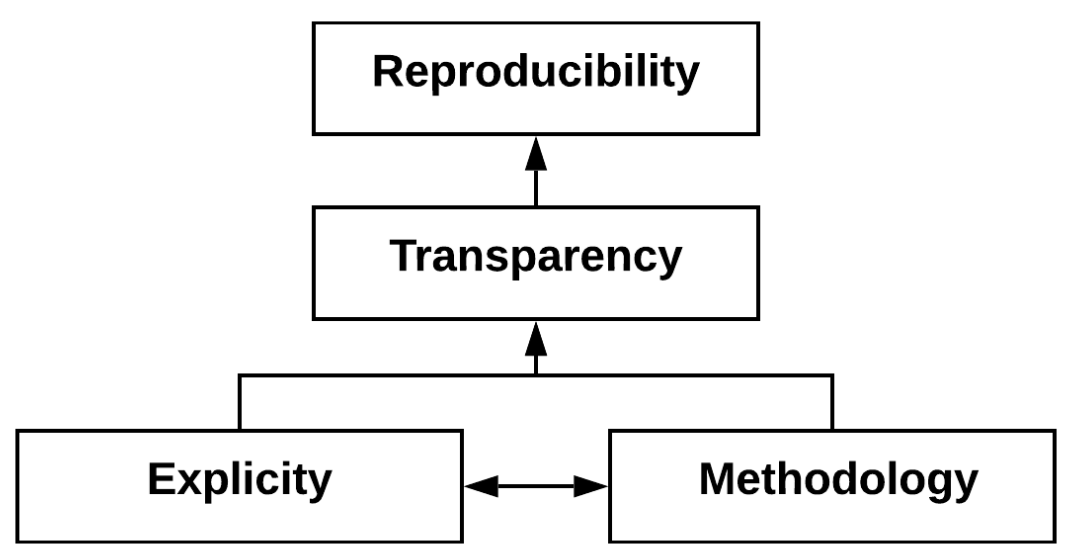

Figure 2: Reproducibility as a minimum requirement for literature reviews

Our research question can now be specified as follows: which methodological details are explicitly provided in literature review studies with a VET-related focus, and which ones are not? We expect that this research question is sufficiently broad to be inclusive of all types of literature review studies with a transparent methodology (Gough et al., 2012b).

The overall purpose of our umbrella review is an assessment for which a conceptual framework is required. The first step is, therefore, to clarify the concept of a review to set the frame for the assessment.

\section{Literature review: definition and epistemology}

\section{$2.1 \quad$ Literature review}

The label literature review is often used in two respects, first, as a categorial term to distinguish among review categories (e.g. literature, financial, workflow and employee performance) and, second, as a specific term to distinguish among literature review types. Grant and Booth (2009) developed an influential typology with 14 types of reviews. They defined a literature 
review (as a specific term) as follows: the "common characteristics are that a literature review reviews published literature, implying that included materials possess some degree of permanence and, possibly, have been subject to a peer-review process" (Grant \& Booth, 2009, p. 97). This broad definition is appropriate for all literature review types. The authors stated that a literature review as a review type is a "generic term" (p. 94). While the label classifying a review category is appropriate, its usage in classifying a review type within this category is problematic. Therefore, we use the literature review label only as a categorial term. Another review type in Grant and Booth's typology, the overview, is also a "generic term" (p. 94), and for us, it is also a categorial term, not a specific term for a review type.

\subsubsection{Definition}

Hart (2018) subdivided a literature review as a categorial term into two stages: search of the literature and review of the literature. A literature review starts with

a systematic search of the accredited sources and resources. It involves identifying paper and electronic sources relevant to your topic and method(s) by preparing a clear plan for the search that includes a justifiable vocabulary that defines what will and will not be included in the search. (p. 3)

The review of the literature is

the analysis, critical evaluation and synthesis of existing knowledge relevant to your research problem. ... In your analysis, you are selecting from different texts, concepts, theories, arguments and interpretations that seem to be relevant to the development of your particular theoretical frame of reference and/or use of a particular methodology. It involves classifying these parts into schemes that enable you to critically evaluate those concepts, arguments and different interpretations. (pp. 3-4)

The synthesis of existing knowledge is "the act of making connections between the parts identified in the analysis. It is not simply a matter of reassembling the parts back into the original order, but looking for a new order" (p. 197). A literature review, therefore, contains at least the following basic steps: (1) definition of the scope (specify the research problem and the research question); (2) data selection (define the sources and the search terms, and include the relevant research); (3) data processing (analysis: select from different texts, and critically evaluate the extractions; synthesis: pool the extracted data).

Grant and Booth (2009) also focused on the "processes required in completing a review" (p. 104) and identified four "main phases of each review type" (p. 106), "namely search, appraisal, synthesis and analysis" (p. 104). Prior to the synthesis and analysis, the authors situated the appraisal task, whose function is to evaluate the quality of research before it is included in the body of pooled knowledge. Poor research can, therefore, be excluded. Based 
on a government-funded initiative to apply systematic research synthesis in education, the reviewers identified "particular gaps in the methodology of research synthesis, among which the lack of agreed quality criteria for establishing the validity and reliability of 'qualitative' research is probably the most critical." (Oakley, 2002, p. 279). Grant and Booth accordingly stress the importance of quality appraisal: "However, whether the evidence takes the form of primary or secondary studies, it is equally important to undertake an appraisal of quality. This should consider both its robustness (validity and reliability) and its relevance to the local context (applicability)." (Grant \& Booth, 2009, p. 104). The authors also reordered the steps and positioned the analysis after the synthesis. In a later publication, Booth et al., (2016b, p. 172) justified this inverse order with reference to the need for a meta-analysis. Coughlan and Cronin (2017) also included the critical appraisal step and the re-analysis of the pooled data task (p. 45), though within the data synthesis step. Their proposal was not limited to a metaanalysis. Coughlan and Cronin (2017) also extended the systematic search step to search and eligibility screening and added the final step, which comprised the conclusion, discussion and limitations.

Based on the definition of Card, that literature reviews are "systematic syntheses of previous work around a particular topic" (2010, p. 725), we can now extend Hart's (2018) framework to define our understanding of a literature review. To conclude, a literature review contains the following steps: (1) definition of the scope (specify the research problem and research question); (2) data selection (systematic search and eligibility screening: define the sources and search terms, include the relevant research, and screen and read the selected research to exclude the ineligible research); (3) data processing (critical appraisal: assess the quality of the selected research to exclude poor or inappropriate research; analysis: select the relevant data from the different texts, and critically evaluate the extraction; synthesis: synthesise and re-analyse the pooled data) and (4) data reporting (present the findings, and discuss the conclusions and limitations of the review). This is not the definition of a special literature review type but a categorial definition of a literature review.

\subsubsection{Systematic and subjective syntheses}

We are aware that the methodological requirements defined herein are not typical of subjective reviews, which "tend to be idiosyncratic. Subjective reviews choose articles without justifying why they are selected, and they may give equal credence to good and poor studies. The results of subjective reviews are often biased on a partial examination of the available literature, and their findings may be inaccurate or even false" (Fink, 2020, p. 16). Fink distinguished narrative reviews from these subjective reviews. A narrative review may be appropriate "for describing the history or development of a problem and its solution" (p. 16). The purpose of a narrative review is "to identify a few studies that describe a problem of interest. 
... No standards or protocols guide the review. Although the reviewers will learn about the problem, they will not arrive at a comprehensive understanding of the state of the science related to the problem" (Demiris et al., 2019, p. 32). Therefore, also a narrative review "is very subjective depending on what you select, how you choose to use what you found, and how you choose to frame it. It's all subjective. ... so when you look at the quality of a narrative review, a lot of times who wrote it comes into play" (interview with Margaret Foster ${ }^{1}$, as cited in Wang, 2019, p. 4). Subjective and narrative reviews are thus comparable in their approach, which is why we characterize both as subjective syntheses.

In this umbrella review, we do not examine the expertise of the reviewer (an experienced or inexperienced scholar). Instead, in line with our research question, we focus on the "increasing emphasis on reviews that are methodical" (Coughlan \& Cronin, 2017, p. 12). Therefore, we distinguish between (1) systematic syntheses based on an explicitly described methodology of searching, selecting and synthesizing the relevant body of knowledge and (2) subjective syntheses which lack such methodology. Only reviews with an explicitly described methodology are eligible for this umbrella review (Figure 3).

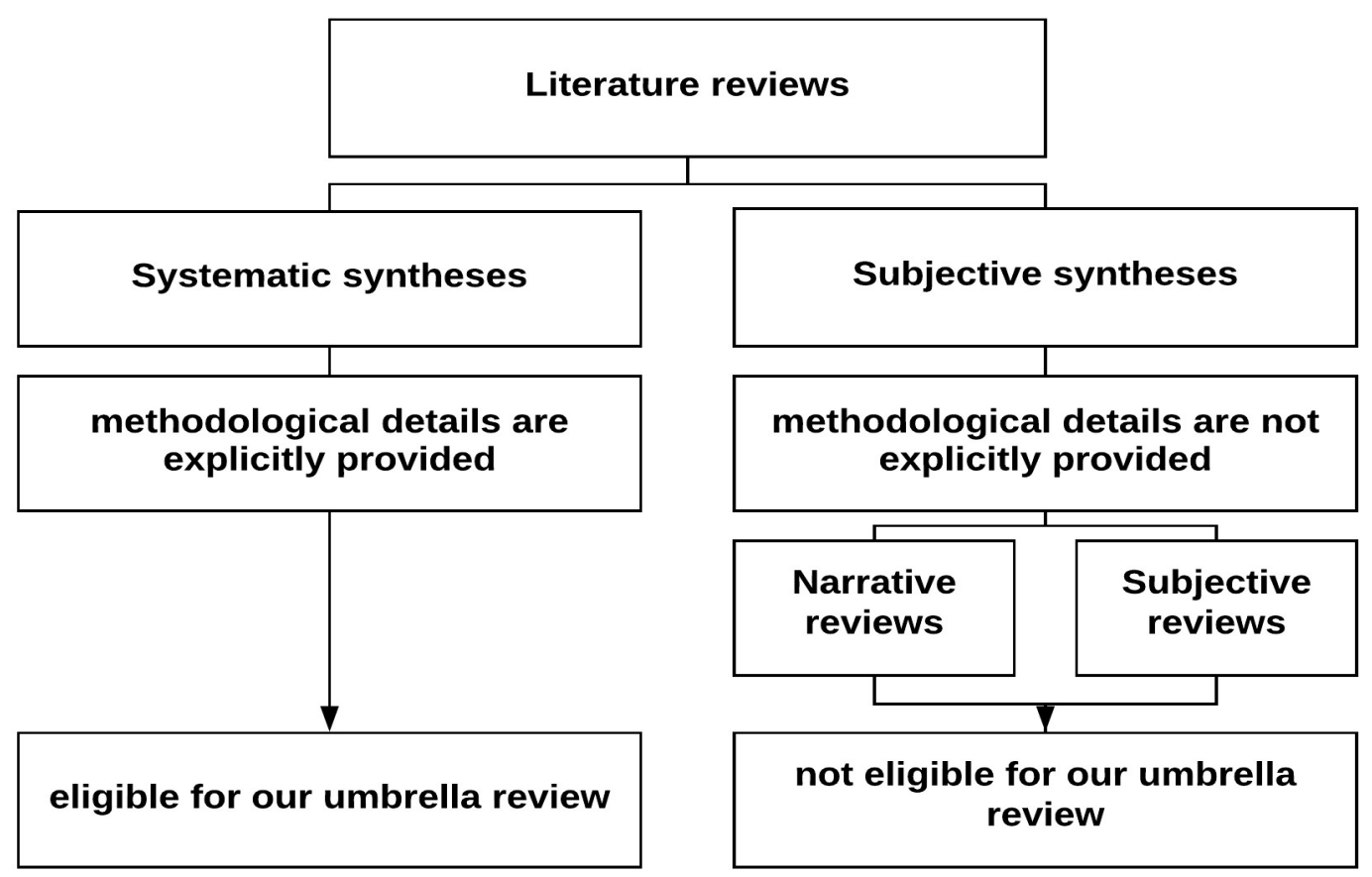

Figure 3: Systematic and subjective syntheses

1 Margaret Foster is the "co-author of the only book written on systematic reviews for librarians, Assembling the Pieces of a Systematic Review: A Guide for Librarians" (Wang, 2019, p. 2) 
An example of a subjective synthesis is a recently published literature review about major strands of African VET literature and emergent approaches. The review was written by a team of experts in the field. However, its methodological foundation - e.g. the selection of literature, the identification of the major and emergent approaches, the qualitative analysis and synthesis - is unclear. According to the authors, the "article draws on team members' experiences of previous attempts to summarise the literature on VET in Africa" (McGrath et al., 2019, p. 3). The lack of methodological explanations has three consequences. (1) The findings are difficult to classify and value. (2) It is difficult to reproduce the review and to verify the findings. (3) A systematic widening or updating of the findings is difficult, even for the authorial team. The tacit methodology is situated and socially embedded in the configuration of the team.

Excluding subjective syntheses from our umbrella review does not mean that these reviews, in general, or the excluded reviews, in particular, are not valuable. But, the excluded reviews (Figure 5) were ineligible within the focus of this study.

\subsubsection{Inappropriate terms}

Descriptions are basic aspects of reviews and are used in many review types. A description "tells us how things are. It is not an argument. It is an account, always written from a certain point of view, to some purpose. A description doesn’t explain" (Jesson et al., 2011, p. 66). As such, we use descriptive review not as a specification for one review type. The terms analytical review and synthesis review are also inappropriate for specifying review types. Analysis and synthesis are key elements in every review. The purpose of a literature review, as a secondorder research, is to analyse and synthesise existing research. The other terms that are sometimes used - state-of-the-art review, systematised review and systematic search and review are also generic characterisations, as pooling the state-of-the-art research is a central purpose of every second-order research. Thus, an explicit methodology is a basic requirement for eligibility in this umbrella review. The term systematic review is nevertheless included in our typology because specific methodologies were developed for this review type (e.g. Moher et al., 2009; Petticrew \& Roberts, 2006; critical: MacLure, 2005). In Table 1, we summarise the terms that we later not use to specify our review types. 
Table 1: Generic or inappropriate terms

\begin{tabular}{|l|l|}
\hline Term & Reason for not using the terms to specify review types \\
\hline Literature review & Generic term \\
\hline Overview & Generic term \\
\hline Descriptive review & Descriptions are used in different types of reviews \\
\hline Analytical review & Conducting an analysis is a basic requirement for every review \\
\hline Synthesis review & Conducting a synthesis is a basic requirement for every review \\
\hline State-of-the-art review & Identifying the state-of-the-art research is a basic purpose of every review \\
\hline Systematised review & Systematic work (or systematised work) is a basic prerequisite for any research \\
\hline Systematic search and review & \\
\hline
\end{tabular}

In the first step, we defined literature review as a categorial term. In the second step, we distinguished literature reviews with an explicit methodology from those with an unclear methodology (subjective reviews and often narrative reviews). In the third step, we identified inappropriate terms. In the next step we will examine the epistemological principles underlying the literature review in order to have a basis for the development of our typology.

\subsection{Epistemological foundation}

According to Toye et al., "a central distinction between synthesis approaches is (a) those that that aim to describe or 'aggregate' findings and (b) those that aim to interpret these findings and develop conceptual understandings or 'theory'" (2014, p. 4). Barnett-Page and Thomas (2009, p. 9) followed the same idea, though with a different purpose. They did not focus on purposes (e.g. aggregation) but on the underlying epistemologies and named their pair of opposites as realist and idealist. They did not make a distinction and assumed that "it is generally a question of degree rather than of absolute distinctions" (Barnett-Page \& Thomas, 2009, p. 9). In Table 2, we summarise the two extreme epistemological positions (idealist and realist) and add the purposes (Toye et al., 2014) and basic review types (Booth et al., 2016b) that are grounded on these epistemologies. 
Table 2: Realist and idealist epistemologies

\begin{tabular}{|c|c|c|}
\hline Epistemologies & Idealist & Realist \\
\hline \multicolumn{3}{|l|}{ (Barnett-Page \& Thomas, 2009) } \\
\hline Searching & Iterative & Linear \\
\hline Quality assessment & $\begin{array}{l}\text { Less clear, less a priori; quality of content } \\
\text { rather than method }\end{array}$ & Clear and a priori \\
\hline Problematising the literature & Yes & No \\
\hline Question & Explore & Answer \\
\hline Heterogeneity & High & Low \\
\hline Synthesised product & Complex & Clear for policy makers and practitioners \\
\hline \multicolumn{3}{|l|}{ (Toye et al., 2014) } \\
\hline Purpose & $\begin{array}{l}\text { "interpret ... findings and develop con- } \\
\text { ceptual understandings or 'theory"' (p. } 4 \text { ) }\end{array}$ & "describe or 'aggregate' findings" (p. 4) \\
\hline \multicolumn{3}{|l|}{ (Booth et al., 2016b) } \\
\hline Basic review types & $\begin{array}{l}\text { Interpretive/configurative reviews "seek } \\
\text { to broaden our understanding of a parti- } \\
\text { cular intervention or phenomenon. Each } \\
\text { study holds the potential to contribute } \\
\text { additional insights and also contribute to } \\
\text { the overall picture" (p. 22). }\end{array}$ & $\begin{array}{l}\text { Aggregative reviews "bring together stu- } \\
\text { dies on a similar topic such that each } \\
\text { additional study adds 'weight' to a shared } \\
\text { finding. Bringing studies together in this } \\
\text { way necessitates assumptions about how } \\
\text { similar studies are to one another (ho- } \\
\text { mogeneity)" (p. 22). }\end{array}$ \\
\hline
\end{tabular}

Following the idea of a continuum, a purpose between the idealist and realist camps can be identified, which we call clarification. This purpose is based on the interpretation and/or aggregation of prior findings for the purpose of clarifying a concept or method as a basis for further development of a theory or methodology. Some helpful umbrella reviews focus on clarification of methodological basics (e.g. Booth et al., 2016a; Grant \& Booth, 2009).

\section{Conceptual framework of literature reviews}

Our conceptual framework (Imenda, 2014) is based on Barnett-Page and Thomas (2009) realist-idealist continuum, from which we make distinctions regarding the review purposes of interpretation, clarification and aggregation.

In section 2, we identified generic, ineligible and inappropriate terms. Without these terms, we are left with the following review types from Grant and Booth's (2009) typology: critical review, mapping review, meta-analysis, mixed studies review, qualitative systematic review, rapid review, scoping review, systematic review and umbrella reviews. In our typology, we did not distinguish between qualitative systematic review and systematic review. Although different, they belong to the same review type, which we call systematic review. For the 
same reason, we grouped mapping review and scoping review under one review type. With the remaining specific review types, we developed our integrated conceptual framework based on the epistemologies, basic review types and purposes presented in Section 2.

Grant and Booth (2009) developed their typology inductively and used published review studies as the bases for their analysis. This approach produced theoretical gaps, as it relates to a given and selected practice. In our framework, we added four review types to fill the gaps: meta-meta-analysis, methodological review, conceptual review and meta-synthesis. Figure 4 presents the integrated conceptual framework with the different review types.

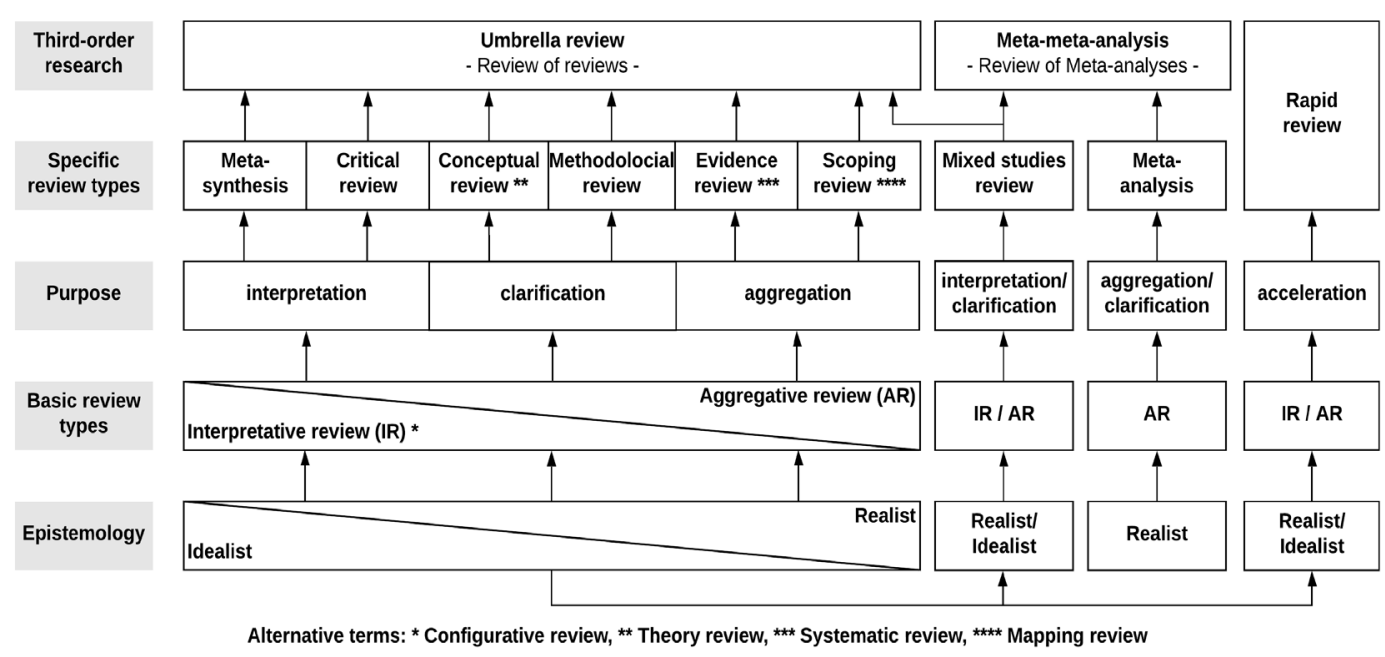

Figure 4: Integrated conceptual framework

These different review types can be used as a single approach, as a sequentially combined approach or as a methodologically combined approach. For example, a review can start sequentially as a meta-synthesis and move on to a critical review. The rapid review approach, on the other hand, is not a stand-alone method, but only possible in combination with another approach (e.g. conceptual review). In Table 3, we summarise the definitions of the different types of methodological literature reviews in our integrated conceptual framework. 
Table 3: Definitions of reviews

\begin{tabular}{|c|c|c|}
\hline Purpose & Review type & Definition \\
\hline \multirow[t]{2}{*}{ Interpretation } & Metasynthesis & $\begin{array}{l}\text { It "is more than a summing up of research findings; it involves } \\
\text { analyses and theory generating syntheses that remain faithful to } \\
\text { the interpretive rendering in each study ... Metasynthesis is de- } \\
\text { fined as interpretive synthesis of data, including phenomenolo- } \\
\text { gies, ethnographies, grounded theories and other integrated and } \\
\text { coherent descriptions or explanations of phenomena, events or } \\
\text { cases" (Bondas \& Hall, 2007, p. 115). }\end{array}$ \\
\hline & Critical review & $\begin{array}{l}\text { It "aims to demonstrate [that the] writer has extensively re- } \\
\text { searched [the] literature and critically evaluated its quality. [It] } \\
\text { goes beyond mere description to include degree of analysis and } \\
\text { conceptual innovation. [It] typically results in [a] hypothesis or } \\
\text { [a] model" (Grant \& Booth, 2009, p. 94). }\end{array}$ \\
\hline \multirow[t]{2}{*}{ Clarification } & $\begin{array}{l}\text { Conceptual review } \\
\text { Alternative term: } \\
\text { Theory review }\end{array}$ & $\begin{array}{l}\text { Conceptual reviews examine concepts "in order to clarify their } \\
\text { characteristics, thereby achieving a better understanding of } \\
\text { the meaning of [those] concept[s]" (Coughlan \& Cronin, 2017, } \\
\text { p. 158). The review can also focus on a broader framework, a } \\
\text { system of concepts, a theory. A theory review "could have one } \\
\text { or more of the following aims: identifying and mapping a com- } \\
\text { prehensive range of relevant theories; assessing which theories } \\
\text { have become influential and which have been, or have become } \\
\text { over time, largely overlooked; and integrating complementary } \\
\text { theories and facilitating the analysis and synthesis of theories } \\
\text { into more generalised or abstract 'meta-theories"' (Campbell et } \\
\text { al., 2014, p. 2). }\end{array}$ \\
\hline & Methodological review & $\begin{array}{l}\text { "The purpose of the methodological review is to understand the } \\
\text { quality of the research by systematically analyzing the various re- } \\
\text { search components of each study and synthesizing the quality of } \\
\text { the research methods across the body of studies" (Krezmien et } \\
\text { al., 2017, p. 105). }\end{array}$ \\
\hline \multirow[t]{2}{*}{ Aggregation } & $\begin{array}{l}\text { Evidence review } \\
\text { Alternative term: } \\
\text { Systematic review }{ }^{2}\end{array}$ & $\begin{array}{l}\text { It is "a process that uses an explicit and transparent methodology } \\
\text { to re-analyse and synthesise evidence from previously conducted } \\
\text { research studies on a given topic" (Coughlan \& Cronin, 2017, p. } \\
\text { 163). }\end{array}$ \\
\hline & $\begin{array}{l}\text { Scoping review } \\
\text { Alternative term: } \\
\text { Mapping review }\end{array}$ & $\begin{array}{l}\text { "A scoping review or scoping study is a form of knowledge syn- } \\
\text { thesis that addresses an exploratory research question aimed at } \\
\text { mapping key concepts, types of evidence, and gaps in research } \\
\text { related to a defined area or field by systematically searching, } \\
\text { selecting, and synthesizing existing knowledge" (Colquhoun et } \\
\text { al., 2014, p. } 1292 \text { f). "Scoping reviews have great utility for syn- } \\
\text { thesizing research evidence and are often used to map existing } \\
\text { literature in a given field in terms of its nature, features, and vo- } \\
\text { lume. As such, scoping reviews have also been called 'mapping' } \\
\text { reviews" (Peters et al., 2015, p. 141). Limitation: "They do not, for } \\
\text { example, appraise the quality of evidence in the primary research } \\
\text { reports in any formal sense" (Arksey \& O'Malley, 2005, p. 30). } \\
\text { Reporting: Tricco et al., } 2016\end{array}$ \\
\hline
\end{tabular}

2 We prefer the term "evidence review" (Munn et al., 2018) because this term indicates the subject or what of the review, not the method or how of a review. Moreover, if one review type claims to be systematic, this would mean that all other review types do not meet this requirement. We have nevertheless used the term "systematic review" (as an alternative term) because specific procedures exist for this type of review and it is popular and widely used (especially in medicine). 


\begin{tabular}{|l|l|l|}
\hline $\begin{array}{l}\text { Interpretation } \\
\text { and } \\
\text { clarification }\end{array}$ & Mixed studies review & $\begin{array}{l}\text { A review of mixed studies "refers to any combination of methods } \\
\text { where one significant component is a literature review (usually } \\
\text { systematic). Within a review context, it refers to a combination } \\
\text { of review approaches, for example combining quantitative with } \\
\text { qualitative research or outcome with process studies" (Grant \& } \\
\text { Booth, 2009, p. 94). }\end{array}$ \\
\hline $\begin{array}{l}\text { Aggregation } \\
\text { and } \\
\text { clarification }\end{array}$ & Meta-analysis & $\begin{array}{l}\text { It is a "technique that statistically combines the results of quan- } \\
\text { titative studies to provide a more precise effect of the results" } \\
\text { (Grant \& Booth, 2009, p. 94). }\end{array}$ \\
\hline $\begin{array}{l}\text { Process accele- } \\
\text { ration }\end{array}$ & Rapid review & $\begin{array}{l}\text { The rapid review approach is a type of systematic syntheses in } \\
\text { which "review processes are accelerated and methods are stream- } \\
\text { lined to complete the review more quickly" (Langlois et al., 2017, } \\
\text { p. 3). Methods are either reduce the research scope, focused } \\
\text { search strategies, or focused methods for the data extraction, } \\
\text { analysis and synthesis (Ganann et al., 2010). }\end{array}$ \\
\hline $\begin{array}{l}\text { Review of } \\
\text { reviews }\end{array}$ & $\begin{array}{l}\text { It "specifically refers to [a] review compiling evidence from } \\
\text { multiple reviews into one accessible and usable document. [It] } \\
\text { focuses on [a] broad condition or problem for which there are } \\
\text { competing interventions and highlights reviews that address the- } \\
\text { se interventions and their results" (Grant \& Booth, 2009, p. 95). }\end{array}$ \\
\hline $\begin{array}{l}\text { Review of } \\
\text { meta-analysis }\end{array}$ & Meta-meta-analysis & $\begin{array}{l}\text { A "meta-meta analysis uses as its basic data individual meta- } \\
\text { analyses. By using meta-analysis as the individual unit of study } \\
\text { (subject), much greater generality is afforded. The reason for this } \\
\text { is that a meta-meta analysis takes into account more techniques } \\
\text { [. and subjects than all previous methods of evaluation; it inte- } \\
\text { grates research through statistical analysis of individual studies" } \\
\text { (Kazrin et al., 1979, p. 397). }\end{array}$ \\
\hline
\end{tabular}

In the following section, we use the generic definition of a literature review from section 2 to develop our methodological framework for the review of reviews.

\section{Methodological framework of literature reviews}

Following our definition, a literature review contains the following steps: (1) definition of the scope (specify the research problem and research question); (2) data selection (systematic search and eligibility screening: define the sources and search terms, include the relevant research, and screen and read the selected research to exclude the ineligible research); (3) data processing (critical appraisal: assess the quality of the selected research to exclude poor or inappropriate research; analysis: select the relevant data from the different texts, and critically evaluate the extraction; synthesis: synthesise and re-analyse the pooled data) and (4) data reporting (present the findings, and discuss the conclusions and limitations of the review). This is not the definition of a special review type but a categorial definition of a literature review. Based on these steps, we developed a methodological framework to assess the methods used. We developed our framework in three steps: (1) synthesising existing approaches (Aromataris \& Pearson, 2014; Aromataris et al., 2015); (2) selecting the methodological criteria (Sny- 
der, 2019) and (3) adjusting the criteria (Strandberg \& Simpson, 2019). The full framework is presented in Table 4.

Table 4: Methodological framework of literature reviews

\begin{tabular}{|c|c|c|c|}
\hline \multicolumn{2}{|c|}{ Process step } & Elements & Items \\
\hline \multirow[t]{4}{*}{1} & \multirow[t]{4}{*}{ Scope definition } & \multirow[t]{2}{*}{ research problem } & research problem is clearly reported ${ }^{*}$ \\
\hline & & & research problem is embedded in the context of what is already known \\
\hline & & \multirow[t]{2}{*}{ research question } & objectives (purpose of review) are clearly reported ${ }^{*}$ \\
\hline & & & research questions are clearly reported \\
\hline \multirow[t]{8}{*}{2} & \multirow[t]{8}{*}{ Data selection } & \multirow[t]{2}{*}{ sources } & the selected sources (e.g. databases) are clearly reported ${ }^{*}$ \\
\hline & & & the reasons for the source selection are clearly stated \\
\hline & & \multirow[t]{2}{*}{ search } & the search strategy is clearly reported \\
\hline & & & the search terms and limits are clearly reported \\
\hline & & \multirow[t]{4}{*}{ eligibility } & $\begin{array}{l}\text { the process of screening (title, abstract) and full text reading is clearly } \\
\text { reported }\end{array}$ \\
\hline & & & the reasons for the inclusion of studies are clearly stated ${ }^{*}$ \\
\hline & & & the reasons for the exclusion of studies are clearly stated \\
\hline & & & $\begin{array}{l}\text { an overview (e.g. flow diagram) is given including the steps identifica- } \\
\text { tion (search) and eligibility, the numbers of included and excluded stu- } \\
\text { dies and the rationale (criteria) for the exclusion of studies. }\end{array}$ \\
\hline \multirow[t]{9}{*}{3} & \multirow[t]{9}{*}{ Data processing } & \multirow[t]{3}{*}{ appraisal } & $\begin{array}{l}\text { criteria or used checklist for the appraisal of the studies is clearly re- } \\
\text { ported }\end{array}$ \\
\hline & & & how the appraisal was done is clearly reported \\
\hline & & & $\begin{array}{l}\text { excluded studies are clearly reported and the reasons for the exclusion of } \\
\text { studies are clearly stated }\end{array}$ \\
\hline & & \multirow[t]{3}{*}{ analysis } & $\begin{array}{l}\text { method(s) of data extraction from reports is clearly reported }{ }^{*} \text {, and the } \\
\text { reason/s for using it is/are clearly stated }\end{array}$ \\
\hline & & & $\begin{array}{l}\text { method(s) of analysis is clearly reported, and the reason/s for using it is/ } \\
\text { are clearly stated }\end{array}$ \\
\hline & & & the result of extraction and analysis is critical evaluated \\
\hline & & \multirow[t]{3}{*}{ synthesis } & method(s) of synthesizing the analysis results are clearly reported ${ }^{\star}$ \\
\hline & & & $\begin{array}{l}\text { method(s) of re-analysis (if appropriate) of the synthesis results are } \\
\text { clearly reported }\end{array}$ \\
\hline & & & $\begin{array}{l}\text { the relation between synthesis results and research question is clearly } \\
\text { reported }\end{array}$ \\
\hline \multirow[t]{4}{*}{4} & \multirow[t]{4}{*}{ Data reporting } & \multirow[t]{2}{*}{ findings } & summarized findings are clearly reported \\
\hline & & & limitations of the study and findings are clearly reported \\
\hline & & \multirow[t]{2}{*}{ conclusion } & $\begin{array}{l}\text { a general interpretation of the results in the context of other studies is } \\
\text { provided }\end{array}$ \\
\hline & & & implications for future research are provided \\
\hline
\end{tabular}

This framework should be seen as a minimum standard. Further steps and criteria could be added (e.g. Aromataris et al., 2015; Moher et al., 2009). 


\section{Review of reviews: rapid methodological umbrella review}

Our review type is, first and foremost, an umbrella review, as our primary purpose is to review existing reviews (Aromataris et al., 2015). Second, we employed the rapid review approach by applying two focused search strategies to accelerate the process (Langlois et al., 2017). (a) Source strategy: we identified the journals and articles by using two databases (Scopus and World of Science). (b) Limitation strategy: we concentrated our search on articles in peer-reviewed journals, which were published in English between 2014 and 2019 in journals with a substantial VET focus. Thirdly, we have analysed the review methods used. Our review is therefore a methodological review (Krezmien et al., 2017).

The following sections describe the details about these combined approaches. The process is directed by the steps outlined in Table 4 .

\subsection{Scope definition}

\subsubsection{Research problem}

We described the research problem in section 1 as a discrepancy between increased VET-focused research, on the one hand, and only a few synthesizing studies, on the other. While this quantitative shortfall is evident, what is not evident is whether the methodological quality of the reviews is appropriate to fulfil the central methodological task of research, i.e. transparency, reproducibility and verifiability/falsifiability.

\subsubsection{Research question}

Our objective is to identify the methodological quality of reviews in VET and to clarify the methodological foundation of a selected corpus of recent reviews. Our research question is: which methodological details are explicitly provided in literature reviews published in peerreviewed journals with a substantial VET focus, and which ones are not?

\subsection{Data selection}

\subsubsection{Sources}

We included in our restricted search two curated databases: Elsevier's Scopus and Clarivate's Web of Science (WoS). Both databases index peer-reviewed literature that have been accepted for inclusion following an internal review (SCOPUS: Content Selection and Advisory 
Board; WoS: inhouse editors). After the inclusion, the journals remain under permanent review. The continuous review of the corpus is important because some journals change after inclusion into "predatory journals" (footnote 4). Both databases index documents from different publishers - the content is publisher-independent. In a more comprehensive search, further databases could be included, such as ERIC (Education Resources Information Center), VOCEDplus (Vocational Education and Training Research Database), JSTOR (Journal STORage), databases from ProQuest (e.g. Education Collection, Social Science Database) and EBSCO (e.g. Education, Research Complete, Business Source Complete), subject-specific databases (PsycINFO, PSYNDEX, SocINDEX), cross-country databases (ASEAN Citation Index, LatinIndex Sistema Regional de Información en Línea para Revistas Científicas de América Latina, el Caribe, España y Portugal), country-specific databases (e.g. CHSSCD Chinese Humanities and Social Sciences Citation Database, PEDOCS Pedagogical Documents, Germany) and publisher-specific databases (e.g. ScienceDirect, Taylor and Francis Online). An additional search approach could be the use of academic search engines, such as Google Scholar and Microsoft Academic (Rovira et al., 2019), or scholarly citations engines, such as Crossref and Dimensions (Harzing, 2019).

\subsubsection{Search}

In the first step, we identified journals with a substantial VET focus for inclusion in our search. The focus on VET was identified by dividing a ratio between the total number of articles (in a certain time) and the total number of articles with a vocational topic. In the second step, we identified the articles with review in the title within these journals. These steps will now be explained in greater detail.

\section{Identification of journals for inclusion}

First, we identified SCOPUS articles published between 2014 and 2018 in English and in the subject area of social sciences, with vocation ${ }^{*}$ in the title, abstract or keyword ${ }^{3}$. The search (15 June 2019) resulted in 3,870 records. From the journal list, we selected the twenty journals with the highest number of VET-related articles and calculated a ratio to identify the VET profile of the journal: 1) total number of VET-related articles (2014-2018) divided by the 2) total number of published articles (2014-2018). This 3) ratio indicates the VET focus of a journal. We set the cut-off value for the ratio at 0.20 . Of the identified journals, nine met this criterion and were included in our search. The results of the selection are shown in Table 5.

\footnotetext{
3 DOCTYPE(ar OR re) AND PUBYEAR > 2013 AND PUBYEAR < 2019 AND LANGUAGE(English) AND SUBJAREA(soci) AND TITLE-ABS-KEY(vocation $\left.{ }^{*}\right)$
} 
Table 5: Journals with VET-focused articles and the identified VET-focus

\begin{tabular}{|c|c|c|c|c|c|c|}
\hline \multicolumn{2}{|r|}{ Journal } & \multirow{2}{*}{$\begin{array}{c}\text { 1) } \\
145\end{array}$} & \multirow{2}{*}{$\begin{array}{c}\text { 2) } \\
145\end{array}$} & \multirow{2}{*}{$\begin{array}{c}\text { 3) } \\
1.00\end{array}$} & \multirow{2}{*}{$\begin{array}{c}\text { 4) } \\
\text { incl. }\end{array}$} & \multirow{2}{*}{ 5) } \\
\hline 1 & Journal of Vocational Education \& Training (JVET) & & & & & \\
\hline 2 & $\begin{array}{l}\text { International Journal for Research in Vocational Education and } \\
\text { Training (IJRVET) }\end{array}$ & 73 & 73 & 1.00 & incl. & 2 \\
\hline 3 & Empirical Research in Vocational Education and Training (ERVET) & 62 & 74 & 0,84 & incl. & 2 \\
\hline 4 & Journal of Vocational Behavior & 62 & 445 & 0.14 & excl. & \\
\hline 5 & Vocations and Learning (VL) & 56 & 92 & 0.61 & incl. & 2 \\
\hline 6 & International Journal of Training Research (IJTR) & 49 & 87 & 0.56 & incl. & $\mathbf{0}$ \\
\hline 7 & Journal of Education and Work (JEW) & 45 & 210 & 0.21 & incl. & 2 \\
\hline 8 & BMC Medical Education & 43 & 1422 & 0.03 & excl. & \\
\hline 9 & Education and Training & 42 & 309 & 0.14 & excl. & \\
\hline 10 & Research in Post Compulsory Education (ROCE) & 39 & 153 & 0.25 & incl. & 2 \\
\hline 11 & Nurse Education Today & 29 & 1333 & 0.02 & excl. & \\
\hline 12 & Review of European Studies & 29 & 392 & 0.07 & excl. & \\
\hline 13 & World Transactions on Engineering and Technology Education & 28 & 498 & 0.06 & excl. & \\
\hline 14 & Journal of Career Development & 27 & 261 & 0.10 & excl. & \\
\hline 15 & Mathematics Education & 27 & 283 & 0.10 & excl. & \\
\hline 16 & Eurasia Journal of Mathematics Science and Technology Education & 26 & 1256 & 0.02 & excl. & \\
\hline 17 & Journal of Technical Education and Training (JTET) & 25 & 47 & 0.53 & incl. & 1 \\
\hline 18 & Pertanika Journal of Social Sciences and Humanities & 23 & 1254 & 0.02 & excl. & \\
\hline 19 & $\begin{array}{l}\text { International Journal for Educational and Vocational Guidance } \\
\text { (IJEVG) }\end{array}$ & 21 & 88 & 0.24 & incl. & 3 \\
\hline 20 & Academic Medicine & 19 & 1399 & 0.01 & excl. & \\
\hline \multicolumn{5}{|c|}{ Total } & 9 & 21 \\
\hline \multicolumn{7}{|c|}{$\begin{array}{l}\text { 1) Number of articles between } 2014 \text { and } 2018 \text { with vocation }{ }^{*} \text { in title, abstract or keyword (database query: } 15 \text { June 2019); 2) } \\
\left.\text { total number of published articles between } 2014 \text { and } 2018 \text { (database query: } 15 \text { June } 2019^{4}\right) ; 3 \text { ) ratio (VET focus); 4) included } \\
\text { journals: (ratio >0.2); 5) number of articles with the term review in the title between } 2014 \text { and } 2019 \text { (last database query: } 15 \\
\text { January } 2020 \text { ). }\end{array}$} \\
\hline
\end{tabular}

In a second step, we cross-checked the results by conducting the same search in Web of Science (WoS), with vocation* as a topic (title, abstract or keyword), and limited the results to articles published in English between 2014 and 2018 in the subject area of education and educational research ${ }^{5}$. Articles from other subject areas and in other languages were again

4 Six journals were excluded in this step because they a) were no longer indexed in Scopus and were b) named on the list of possible predatory (hijacked) journals/predatory publishers (https://predatoryjournals.com): Turkish Online Journal of Educational Technology (excluded from Scopus in 2017), International Journal of Environmental and Science Education (excluded from Scopus in 2016), Man in India (excluded from Scopus in 2017), Asian Social Science (excluded from Scopus in 2015), Mediterranean Journal of Social Sciences (excluded from Scopus in 2015) and Advanced Science Letters (excluded from Scopus in 2017).

5 Scopus does not offer "education" as a subject area in searches, and Web of Science does not offer "social sciences" as a category in searches. "Subject area" (Scopus) and "category" (WoS) have the same function. 
excluded. The search (dated 15 June 2019) resulted in 1,461 records. From the journal list, we again selected twenty journals with the highest number of published VET-related articles and conducted the same calculation as above to determine a VET ratio to identify the VETfocus of the journal. The search confirmed the already identified journals. However, none of the additional journals identified fit the criteria for inclusion. The excluded journals were: Higher Education Skills and Work-based Learning (0.15), Studies in Continuing Education (0.11), Research in Comparative and International Education (0.10), International Journal of Lifelong Learning (0.06), British Educational Research Journal (0.04), Community College Journal of Research and Practice (0.03), International Journal of Educational Development (0.02), Education Science - Theory and Practice (0.02) and Higher Education (0.02).

Based on this pre-selection of journals, we searched the reviews for our umbrella review.

Identification of articles for inclusion

We included all studies in the nine identified journals with review in the title and used similar criteria as in the journal identification process (Table 6).

Table 6: Criteria used to select documents

\begin{tabular}{|l|l|l|}
\hline Criteria & Inclusion & Exclusion \\
\hline Database source & Scopus and Web of Science & ERIC etc. \\
\hline Specific source & 9 journals & Books etc. \\
\hline Document type & Articles and reviews & Editorials etc. \\
\hline Publication period & Between 2014 and 2019 & Before 2014 and after 2019 \\
\hline Language & English & Other languages \\
\hline $\begin{array}{l}\text { Subject area (Scopus)/ } \\
\text { category (WoS) }\end{array}$ & $\begin{array}{l}\text { Social sciences/ } \\
\text { education \& educational research }\end{array}$ & $\begin{array}{l}\text { Other subject areas/ } \\
\text { categories }\end{array}$ \\
\hline
\end{tabular}

A total of 21 studies (date of last search: Jan 15, 2020) were identified in the search: JVET (7), IJEVG (3), ERVET (2), IJRVET (2), JEW (2), ROCE (2), VL (2) and JTET (1). No article containing review in the title was published in IJTR between 2014 and 2019.

\subsubsection{Eligibility}

Following the title and abstract screening, two articles were excluded (Christie, 2017; Spours et al., 2019) because their purpose was not a review of research. They both reviewed practice. After reading the full text, six further review studies were excluded (Avis, 2018; Emmenegger et al., 2019; Guilbert et al., 2016; Little, 2015; McGrath et al., 2019; Small et al., 2018). These review studies were within the scope (literature review), but important methodological details (e.g. the criteria for the inclusion of studies) were not given. These reviews were not 
eligible for this umbrella review (see section 2.1.2 Systematic and subjective syntheses). The flow chart (Figure 5), presents an overview of the search (identification) and eligibility steps (screening and check).

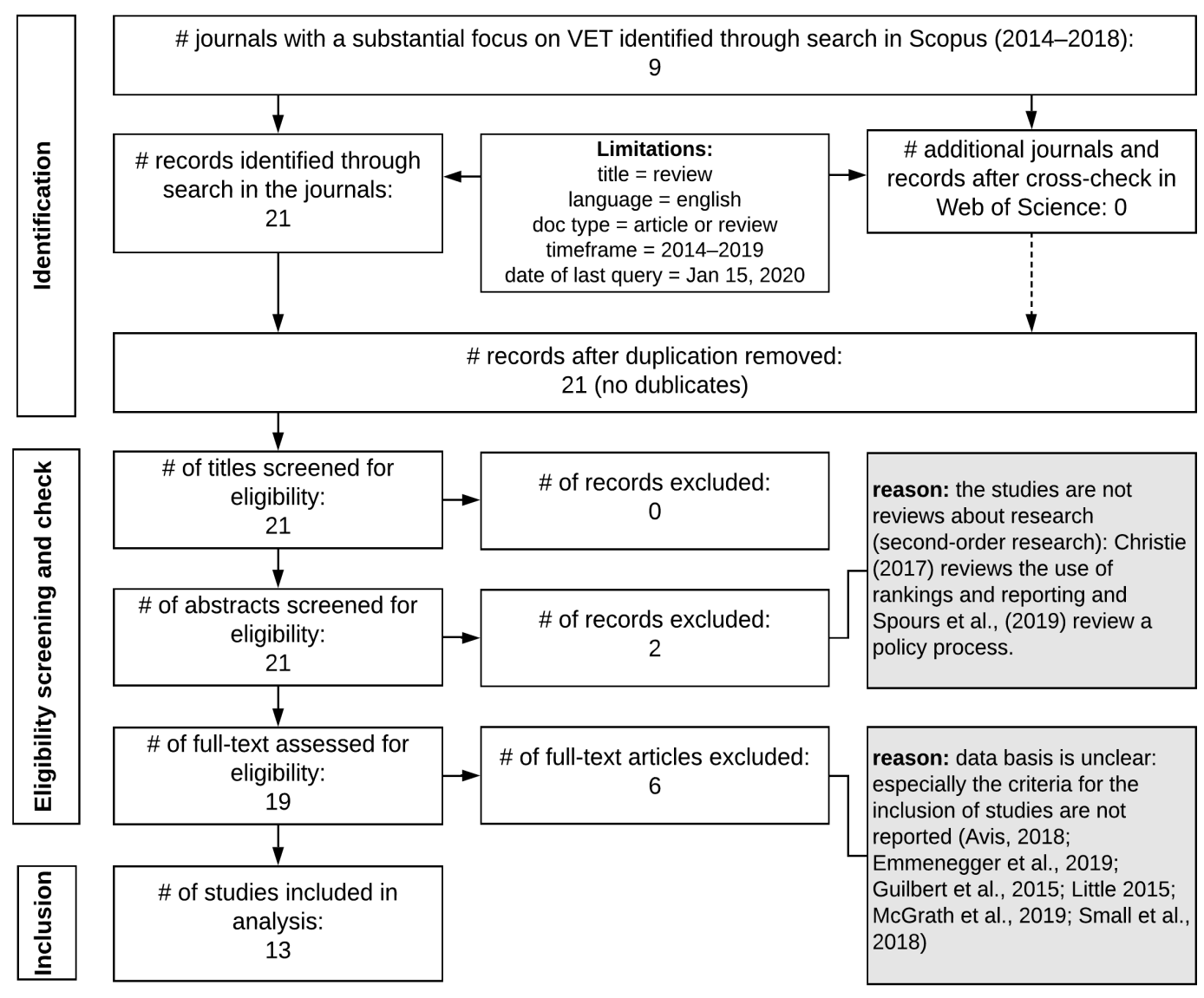

Figure 5: Flow of information through the different steps

In the observation period (2014 to 2019), the nine identified journals with a substantial focus on VET published a total of 1,283 articles, of which only 13 reviews (1.01\% of the articles) dealt with a systematic interpretation, clarification or aggregation of previous research. The included 13 reviews are presented in the overview in the appendix. Based on the review typology we developed, five of the 13 reviews were conceptual in nature, four were scoping reviews, three were evidence-oriented, and one was critical in nature. None of the reviews examined focused on meta-syntheses, research methods or meta-analyses. In total, this resulted in current review gaps with respect to theory generation (meta-synthesis), practice 
of theory elaboration and testing (methodological review) and the determination of overall effects across single studies (meta-analysis).

After identifying the corpus for our umbrella review, we continued with the appraisal, analysis and synthesis.

\subsection{Data processing}

\subsubsection{Appraisal}

Critical appraisal tools are available for many kinds of research studies, such as analytical cross-sectional studies, case control studies, case reports, case series, diagnostic test accuracy studies, economic evaluations, prevalence studies, qualitative research, quasi-experimental studies, randomized controlled trials, systematic reviews, text and opinion studies ${ }^{6}$. We used criteria from an appraisal checklist developed for umbrella reviews (Aromataris et al., 2015), which were also included in our overall methodological framework (Table 4). Each criterion was assessed using the following codes:

$\mathbf{O}=$ yes

$\bigcirc=$ partly

$\mathrm{O}=$ no

Table 7: Appraisal checklist and results

\begin{tabular}{|c|c|c|c|c|c|c|c|c|c|c|c|c|c|}
\hline Items & 1 & 2 & 3 & 4 & 5 & 6 & 7 & 8 & 9 & 10 & 11 & 12 & 13 \\
\hline Research problem is clearly reported & O & ○ & 0 & ○ & O & 0 & O & 0 & ○ & ○ & O & O & ○ \\
\hline $\begin{array}{l}\text { Research objectives are clearly } \\
\text { reported }\end{array}$ & 0 & ○ & 0 & & 0 & - & ○ & 0 & 0 & ○ & O & 0 & O \\
\hline $\begin{array}{l}\text { The selected sources (e.g. databases) } \\
\text { are clearly reported }\end{array}$ & 0 & 0 & 0 & 0 & 0 & 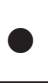 & 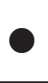 & 0 & 0 & O & O & O & \\
\hline $\begin{array}{l}\text { Reasons why studies have been } \\
\text { included are clearly reported }\end{array}$ & 0 & 0 & 0 & 0 & 0 & 0 & 0 & 0 & 0 & 0 & 0 & 0 & D \\
\hline $\begin{array}{l}\text { Method(s) of data extraction from } \\
\text { reports is clearly reported and } \\
\text { reasoned }\end{array}$ & 0 & 0 & 0 & 0 & 0 & ○ & 0 & 0 & 0 & 0 & 0 & 0 & \\
\hline $\begin{array}{l}\text { Method(s) of synthesizing the ana- } \\
\text { lysis results is clearly reported }\end{array}$ & & 0 & & 0 & 0 & & 0 & & 0 & 0 & 0 & 0 & \\
\hline
\end{tabular}

We defined in advance that only studies that at least partially meet all appraisal criteria will be considered. The evaluation was made by the two authors separately, and the individual results

6 https://joannabriggs.org/ebp/critical_appraisal_tools 
were later discussed and agreed. The result of our appraisal is shown in Table 7. All 13 studies met this minimum requirement.

\section{Exclusion}

No studies were excluded in this step.

\subsubsection{Analysis}

\section{Data extraction}

A data extraction form was developed beforehand, based on the framework to assess the methodology of literature reviews (Table 4), to guide the data extraction.

\section{Analysis}

In the first step, we extracted, independently of each other, the data from one study using our data extraction form and discussed our results, understanding of the criteria and whether our data extraction approach was consistent with the research question and purpose. We clarified our criteria, adapted the form and extracted the data from the remaining twelve studies. Each criterion was assessed using the following codes:

$=$ criterion clearly reported (replication is possible)

$\mathrm{O}=$ criterion partly reported (replication is partly possible)

$\mathrm{O}=$ criterion not reported or unclearly reported (replication is not possible)

\section{Critical evaluation}

The analysis was an iterative process in which we extracted data and updated the data extraction form. After this step, we discussed our emerging results until we reached a common agreement. This step-by-step approach was done to make the criteria consistent and obtain a common understanding of the extracted data (Levac et al., 2010).

\subsubsection{Synthesis}

We summarized the results $\left(\Sigma^{1}\right)$ for each criterion and used this coding for the single ratings: $\Theta=2, \bigcirc=1, \bigcirc=0$. For each line, we calculated the sum and summed up an overall rating with these codings: $26(=100 \%)=$ clearly reported $=0,13-25(\geq 50 \%)=$ mostly clearly reported $=\bigcirc, 0-12(<50 \%)=$ mostly unclearly reported $=\bigcirc$. We also summarized the results for each study and used the same coding $(\mathbf{O}=2, \bigcirc=1, \bigcirc=0)$. For each column, we therefore calcu- 
lated the sum and summed up an overall rating $\left(\Sigma^{2}\right)$ with the same categories $(100 \%, \geq 50 \%$, $<50 \%)$.

Based on our research question (Which methodological details are explicitly provided in literature reviews published in peer-reviewed journals with a substantial VET focus, and which ones are not?), we arrived at three perspectives on the methodological details. (1) Each study was analysed using the 25 criteria of the methodological framework (Table 4). (2) A cross-study assessment was carried out for each criterion. (3) We used the four process steps of a review (scope definition, data selection, data processing, data reporting) to create a summative evaluation for each. The results are presented in the following section.

\section{Re-analysis}

Methods of re-analysis were not applied.

\subsection{Data reporting}

\subsubsection{Overview}

Based on our typology (Table 3, Figure 4), we identified five conceptual reviews, four scoping reviews, three evidence reviews and one critical review (see appendix). A first conclusion is that there were four review types among the thirteen reviews (conceptual, scoping, evidence and critical). While this shows good breadth, the absence of three review types is problematic: (1) a meta-synthesis "involves analyses and theory generating syntheses" (Bondas \& Hall, 2007, p. 115). None of the studies examined was aimed at theory generation. (2) Of the studies examined, none explicitly and exclusively focused on methods. As a sub-category or sub-question, research methods were partially considered (e.g. Schwendimann et al., 2018), but issues relating to research methods were not principally addressed, thus highlighting an important research gap. (3) None of the studies examined were meta-analyses, even though two scoping reviews did at least veer in this direction (Caves et al., 2019; Tonhäuser \& Büker, 2016). The purpose of meta-analyses, i.e. the combination of "the results of quantitative studies to provide a more precise effect of the results" (Grant \& Booth, 2009, p. 94), was not intended in any review. This results in three major review gaps in terms of theory generation, the review of methodology and methods used and the consolidation of empirical results.

The table in the appendix shows substantial differences between the reviews. (1) In eight reviews, a reference provided information about the review method used by the authors, while in five reviews, no such reference was given. (2) Eleven reviews mentioned the period under study, while two reviews provided no such reference. (3) In seven reviews, the included and excluded languages were mentioned. Out of these seven reviews three reviews had 
a focus on multiple languages (not only English). In six reviews, no information was given. However, it can be assumed that languages other than English were not included in the reviews that did not indicate the language used. Finally, the problem of language exclusion was only addressed and reflected on in the review of Schwendimann et al. (2018). Language restrictions can create a systematic selection bias. (4) Many authors (6 of 13) provided no references regarding the basis of the data analysis and synthesis.

\subsubsection{Findings}

The results of the categories research problem and research question are shown in Table 8.

Table 8: Scope definition

\begin{tabular}{|c|c|c|c|c|c|c|c|c|c|c|c|c|c|c|c|}
\hline Elements & Items & 1 & 2 & 3 & 4 & 5 & 6 & 7 & 8 & 9 & 10 & 11 & 12 & 13 & $\Sigma^{1}$ \\
\hline \multirow[t]{2}{*}{$\begin{array}{l}\text { Research } \\
\text { problem }\end{array}$} & $\begin{array}{l}\text { Research problem is } \\
\text { clearly reported }\end{array}$ & 0 & 0 & 0 & 0 & 0 & 0 & 0 & 0 & 0 & 0 & 0 & 0 & 0 & 0 \\
\hline & $\begin{array}{l}\text { Research problem is } \\
\text { embedded in the con- } \\
\text { text of what is already } \\
\text { known }\end{array}$ & 0 & 0 & 0 & 0 & 0 & 0 & 0 & 0 & 0 & 0 & 0 & 0 & 0 & 0 \\
\hline \multirow[t]{2}{*}{$\begin{array}{l}\text { Research } \\
\text { question }\end{array}$} & $\begin{array}{l}\text { Objectives are clearly } \\
\text { reported }\end{array}$ & 0 & 0 & 0 & 0 & 0 & 0 & ○ & 0 & 0 & ○ & 0 & 0 & 0 & ○ \\
\hline & $\begin{array}{l}\text { Research questions } \\
\text { are clearly reported }\end{array}$ & 0 & 0 & ○ & 0 & 0 & 0 & ○ & 0 & 0 & 0 & 0 & ○ & 0 & ○ \\
\hline \multicolumn{2}{|r|}{$x_{1}$} & 0 & 0 & ○ & 0 & 0 & 0 & ○ & 0 & 0 & 0 & 0 & 0 & 0 & () \\
\hline
\end{tabular}

A close examination of the reviews showed that their scope was mostly clearly presented ( 9 clear, 4 partly clear).

The results of the categories sources, search and eligibility are shown in Table 9.

Table 9: Data selection

\begin{tabular}{|c|c|c|c|c|c|c|c|c|c|c|c|c|c|c|c|}
\hline Elements & Items & 1 & 2 & 3 & 4 & 5 & 6 & 7 & 8 & 9 & 10 & 11 & 12 & 13 & $\Sigma^{1}$ \\
\hline \multirow[t]{2}{*}{ Sources } & $\begin{array}{l}\text { The selected sources } \\
\text { (e.g. databases) are } \\
\text { clearly reported }\end{array}$ & 0 & 0 & 0 & 0 & 0 & ○ & 0 & 0 & ○ & 0 & 0 & 0 & 0 & 0 \\
\hline & $\begin{array}{l}\text { The source selection } \\
\text { is reasoned }\end{array}$ & 0 & ○ & 0 & 0 & 0 & ○ & ○ & 0 & 0 & $\bigcirc$ & 0 & 0 & 0 & ○ \\
\hline \multirow[t]{2}{*}{ Search } & $\begin{array}{l}\text { The search terms are } \\
\text { clearly reported }\end{array}$ & 0 & 0 & 0 & 0 & 0 & ○ & 0 & 0 & 0 & 0 & 0 & 0 & 0 & O \\
\hline & $\begin{array}{l}\text { The limitations are } \\
\text { clearly reported }\end{array}$ & 0 & 0 & ○ & 0 & 0 & ○ & $\bigcirc$ & ○ & 0 & 0 & 0 & 0 & 0 & ○ \\
\hline
\end{tabular}

7 The criterion "language" was not considered. Information on how this criterion has been taken into account in the reviews is given in Annex 1. 


\begin{tabular}{|c|c|c|c|c|c|c|c|c|c|c|c|c|c|c|c|}
\hline \multirow[t]{4}{*}{ Eligibility } & $\begin{array}{l}\text { The process of scree- } \\
\text { ning (title, abstract) } \\
\text { and full text reading } \\
\text { is clearly reported }\end{array}$ & 0 & 0 & 0 & ○ & 0 & $\bigcirc$ & $\mathrm{O}$ & ○ & 0 & 0 & O & O & $\bigcirc$ & \\
\hline & $\begin{array}{l}\text { Reasons why studies } \\
\text { have been included } \\
\text { are clearly reported }\end{array}$ & 0 & ○ & 0 & 0 & 0 & 0 & 0 & 0 & O & 0 & 0 & 0 & 0 & 0 \\
\hline & $\begin{array}{l}\text { Reasons why studies } \\
\text { have been excluded } \\
\text { are clearly reported }\end{array}$ & ○ & ○ & $\bigcirc$ & 0 & 0 & $\bigcirc$ & 0 & 0 & 0 & ○ & 0 & 0 & $\bigcirc$ & ○ \\
\hline & $\begin{array}{l}\text { A process overview } \\
\text { (flow diagram) is } \\
\text { given }\end{array}$ & $\bigcirc$ & 0 & $\bigcirc$ & $\bigcirc$ & 0 & O & 0 & O & $\bigcirc$ & ○ & 0 & $\bigcirc$ & $\bigcirc$ & 0 \\
\hline \multicolumn{2}{|l|}{$\Sigma^{2}$} & ○ & ○ & 0 & ○ & 0 & ○ & ○ & ○ & ○ & ○ & ○ & ○ & ○ & ○ \\
\hline
\end{tabular}

With regard to the process step data selection, only one article was complete in terms of our methodological framework. A helpful tool to create transparency in the selection process is the flow chart (see Figure 5). However, of the 13 studies examined, only 3 used this instrument. This is surprising, given that flow charts were recommended in Moher et al. (1999) and again in 2009 "to address the suboptimal reporting of meta-analyses" (Moher et al., 2009, p. 1006). We would like to extend this statement: flowcharts help in countering the suboptimal reporting of reviews.

The results of the categories appraisal, analysis and synthesis are shown in Table 10.

Table 10: Data processing

\begin{tabular}{|c|c|c|c|c|c|c|c|c|c|c|c|c|c|c|c|}
\hline Elements & Items & 1 & 2 & 3 & 4 & 5 & 6 & 7 & 8 & 9 & 10 & 11 & 12 & 13 & $\Sigma^{1}$ \\
\hline \multirow[t]{3}{*}{ Appraisal } & $\begin{array}{l}\text { Criteria, or checklist, } \\
\text { used for the appraisal } \\
\text { of the studies are } \\
\text { clearly reported }\end{array}$ & 0 & O & ○ & ○ & 0 & $\odot$ & ○ & 0 & $\odot$ & ○ & $\bigcirc$ & 0 & ○ & ○ \\
\hline & $\begin{array}{l}\text { How the appraisal } \\
\text { was done is clearly } \\
\text { reported }\end{array}$ & 0 & 0 & 0 & 0 & 0 & 0 & $\bigcirc$ & 0 & 0 & 0 & $\bigcirc$ & 0 & ○ & ○ \\
\hline & $\begin{array}{l}\text { Excluded studies are } \\
\text { clearly reported and } \\
\text { reasoned }\end{array}$ & 0 & ○ & $\bigcirc$ & $\bigcirc$ & 0 & $\bigcirc$ & $\bigcirc$ & 0 & 0 & 0 & 0 & 0 & $\bigcirc$ & ○ \\
\hline \multirow[t]{3}{*}{ Analysis } & $\begin{array}{l}\text { Method(s) of data ex- } \\
\text { traction from reports } \\
\text { is clearly reported } \\
\text { and reasoned }\end{array}$ & 0 & ○ & 0 & 0 & ○ & $\odot$ & 0 & 0 & 0 & 0 & ○ & 0 & 0 & ○ \\
\hline & $\begin{array}{l}\text { Method(s) of analysis } \\
\text { is clearly reported } \\
\text { reasoned }\end{array}$ & 0 & 0 & ○ & 0 & 0 & $\bigcirc$ & $\bigcirc$ & 0 & 0 & 0 & 0 & 0 & 0 & ○ \\
\hline & $\begin{array}{l}\text { The result of the ext- } \\
\text { raction and analysis is } \\
\text { critically evaluated }\end{array}$ & 0 & 0 & ○ & ○ & 0 & $\odot$ & 0 & 0 & $\odot$ & 0 & 0 & ○ & 0 & ○ \\
\hline
\end{tabular}




\begin{tabular}{|c|c|c|c|c|c|c|c|c|c|c|c|c|c|c|c|}
\hline \multirow[t]{3}{*}{ Synthesis } & $\begin{array}{l}\text { Method(s) of syn- } \\
\text { thesizing the analysis } \\
\text { results is clearly } \\
\text { reported }\end{array}$ & 0 & 0 & 0 & 0 & 0 & 0 & 0 & 0 & 0 & 0 & 0 & 0 & 0 & \\
\hline & $\begin{array}{l}\text { Method(s) of re- } \\
\text { analysis (if appropri- } \\
\text { ate) of the synthesis } \\
\text { results is clearly } \\
\text { reported }\end{array}$ & 0 & $\bigcirc$ & $\bigcirc$ & 0 & $\bigcirc$ & $\bigcirc$ & $\bigcirc$ & $\bigcirc$ & $\bigcirc$ & 0 & $\bigcirc$ & $\bigcirc$ & $\bigcirc$ & 0 \\
\hline & $\begin{array}{l}\text { The relation between } \\
\text { synthesis results and } \\
\text { research question is } \\
\text { clearly reported }\end{array}$ & 0 & 0 & 0 & 0 & 0 & 0 & 0 & 0 & 0 & 0 & 0 & 0 & 0 & \\
\hline \multicolumn{2}{|l|}{$\Sigma^{2}$} & 0 & ○ & ○ & ○ & 0 & 0 & ○ & ○ & ○ & ○ & ○ & ○ & ○ & ○ \\
\hline
\end{tabular}

With regard to the process step data processing one article (No 1) was complete in terms of our methodological framework. Because the process step re-analysis is not always appropriate, three further articles (No 5, 8 and 12) can be considered complete.

The results of the categories findings and conclusion are shown in Table 11.

Table 11: Data reporting

\begin{tabular}{|c|c|c|c|c|c|c|c|c|c|c|c|c|c|c|c|}
\hline Elements & Items & 1 & 2 & 3 & 4 & 5 & 6 & 7 & 8 & 9 & 10 & 11 & 12 & 13 & $\Sigma^{1}$ \\
\hline \multirow[t]{2}{*}{ Findings } & $\begin{array}{l}\text { Summarised findings } \\
\text { are clearly reported }\end{array}$ & 0 & 0 & 0 & 0 & 0 & 0 & 0 & 0 & 0 & 0 & 0 & 0 & 0 & 0 \\
\hline & $\begin{array}{l}\text { Limitations of the } \\
\text { study and findings are } \\
\text { clearly reported }\end{array}$ & 0 & ○ & 0 & 0 & 0 & ○ & ○ & 0 & 0 & 0 & ○ & 0 & 0 & ○ \\
\hline \multirow[t]{2}{*}{$\begin{array}{l}\text { Conclu- } \\
\text { sion }\end{array}$} & $\begin{array}{l}\text { A general interpre- } \\
\text { tation of the results in } \\
\text { the context of other } \\
\text { studies is provided }\end{array}$ & 0 & 0 & 0 & 0 & 0 & ○ & ○ & 0 & 0 & 0 & 0 & 0 & 0 & ○ \\
\hline & $\begin{array}{l}\text { Implications for } \\
\text { future research are } \\
\text { provided }\end{array}$ & 0 & 0 & ○ & ○ & 0 & 0 & 0 & 0 & 0 & 0 & 0 & ○ & 0 & ○ \\
\hline \multicolumn{2}{|r|}{$t_{1}$} & 0 & ○ & ○ & ○ & 0 & ○ & ○ & 0 & 0 & 0 & ○ & ○ & 0 & ○ \\
\hline
\end{tabular}

Compared to the previous process categories data selection and data processing, the results of the process category data reporting are better. 


\section{Conclusions}

Our study's results support four conclusions. (1) More systematic syntheses are needed due to a substantial quantitative gap in the review research. (2) In particular, review studies with a focus on meta-synthesis, research methods and meta-analysis are needed. (3) A literature review should be considered a valid research method and thus held to the same scientific rigour as other research methods. Reviews should therefore be based on a research method that includes transparent and reproducible procedures and verifiable or falsifiable findings. (4) In the studies examined, there was a high degree of heterogeneity with regard to the accuracy and completeness of the methodological steps and data. The developed methodological framework can serve as a guideline for conducting review studies in VET research.

Structures and reporting standards, especially in medicine, have been developed over time. However, it is problematic that "we don't have that in other areas, such as education, as we have in medicine. Until you have structure in place, you are going to continue with the question: What did you do?" (Wang, 2019, pp. 8-9). Following this discourse, we propose a clear distinction between systematic syntheses based on an explicitly described methodology of searching, selecting and synthesising the relevant body of knowledge with transparent and reproducible procedures and subjective syntheses (such as narrative and subjective reviews), which lack such methodology. While subjective syntheses are mainly based on presumptive conclusions, they can nevertheless form a basis for systematic syntheses. However, subjective syntheses often do not meet the scientific standards of transparency, reproducibility and verifiability/falsifiability. Systematic syntheses, in turn, can be distinguished according to their subject and purpose (Table 3).

This study is also subject to limitations. To date, no general standards for systematising and typologising reviews have been established. The presented conceptual framework could be therefore more differentiated (Booth et al., 2016a) or even less differentiated (Paré et al., 2015). However, a model should be distinctive, informative and applicable. We assume that the developed model is helpful for specifying the type of review used. The methodological framework could also include further items, e.g. the review has an accessible protocol (Moher et al., 2009), which will probably be the case in the future. Limitations are of course also included in our scope and search process, including that we have not included journals published in languages other than English and journals that are not indexed in the selected databases. This applies, for example, to the German VET journal Zeitschrift für Berufs-und Wirtschaftspädagogik (ZBW), which is not indexed in either SCOPUS or WoS. The publication language is almost exclusively German. A search on 5 January 2020 in the journal ZBW via the database FIS Bildung (searched with the word review in the field FREITEXT, including the title, keywords, and abstract) showed that, between 2014 and 2019, 140 articles were published, of which only 1 (Kayser \& Ziegler, 2014) was referred to as a literature review. In quantitative terms, the results are comparably unsatisfactory. 


\section{Appendix}

\section{Included reviews}

\begin{tabular}{|c|c|c|c|c|c|c|c|c|c|}
\hline No & Author(s) & Title & $\begin{array}{l}\text { Referenced } \\
\text { review } \\
\text { method }\end{array}$ & $\begin{array}{l}\text { Period } \\
\text { covered }\end{array}$ & $\begin{array}{l}\text { Languages } \\
\text { included }\end{array}$ & Sources & $\begin{array}{l}\text { Studies } \\
\text { included }\end{array}$ & $\begin{array}{l}\text { Referenced } \\
\text { analysis method }\end{array}$ & $\begin{array}{l}\text { Review } \\
\text { type }\end{array}$ \\
\hline 1 & $\begin{array}{l}\text { Caves, Baumann, } \\
\text { \& Renold (2019) }\end{array}$ & $\begin{array}{l}\text { Getting there from here: A } \\
\text { literature review on vocatio- } \\
\text { nal education and training } \\
\text { reform implementation }\end{array}$ & $\begin{array}{l}\text { Jesson, } \\
\text { Matheson, \& } \\
\text { Lacey (2011) }\end{array}$ & 1984-2017 & English & 13 databases & 177 & $\begin{array}{l}\text { Contrastive coding based } \\
\text { on a conceptual frame- } \\
\text { work. Subsample analyses } \\
\text { with multivariate statistical } \\
\text { methods. Several reveren- } \\
\text { ces provided. }\end{array}$ & $\begin{array}{l}\text { Scoping } \\
\text { review }\end{array}$ \\
\hline 2 & $\begin{array}{l}\text { Hökkä, Vähäsanta- } \\
\text { nen, \& Paloniemi } \\
\text { (2019) }\end{array}$ & $\begin{array}{l}\text { Emotions in learning at work: } \\
\text { A literature review }\end{array}$ & $\begin{array}{l}\text { No referen- } \\
\text { ces provided }\end{array}$ & $2000-2017$ & $\begin{array}{l}\text { No infor- } \\
\text { mation } \\
\text { provided }\end{array}$ & 2 databases & 31 & $\begin{array}{l}\text { Thematic analysis } \\
\text { (Attride-Stirling, 2001; } \\
\text { Braun \& Clarke, 2006) }\end{array}$ & $\begin{array}{l}\text { Conceptual } \\
\text { review }\end{array}$ \\
\hline 3 & $\begin{array}{l}\text { Haug, Plant, } \\
\text { Valdimarsdóttir, } \\
\text { Bergmo-Prvulovic, } \\
\text { Vuorinen, Lovén, } \\
\text { \& Vilhjálmsdóttir } \\
\text { (2019). }\end{array}$ & $\begin{array}{l}\text { Nordic research on educatio- } \\
\text { nal and vocational guidance: } \\
\text { A systematic literature review } \\
\text { of thematic features between } \\
2003 \text { and } 2016 \text {. }\end{array}$ & $\begin{array}{l}\text { Creswell } \\
\text { (2013); } \\
\text { Hughes, } \\
\text { Mann, Bar- } \\
\text { nes, Baldauf, } \\
\text { \& McKeown } \\
\text { (2016) }\end{array}$ & 2003-2016 & $\begin{array}{l}\text { Danish, Eng- } \\
\text { lish, Finnish, } \\
\text { Icelandic, } \\
\text { Norwegian, } \\
\text { Swedish }\end{array}$ & 5 databases & 290 & $\begin{array}{l}\text { Systematization based } \\
\text { on thematic areas, stated } \\
\text { intentions in the studies, } \\
\text { specific target groups, } \\
\text { and additional thematic } \\
\text { synthesis of preliminary } \\
\text { conclusions (Creswell, } \\
2013 \text { ) }\end{array}$ & $\begin{array}{l}\text { Scoping } \\
\text { review }\end{array}$ \\
\hline 4 & $\begin{array}{l}\text { Chinedu, Wan } \\
\text { Mohamed, \& Ajah } \\
\text { (2018) }\end{array}$ & $\begin{array}{l}\text { A systematic review on } \\
\text { education for sustainable de- } \\
\text { velopment: Enhancing TVE } \\
\text { teacher training programme }\end{array}$ & \begin{tabular}{|l|} 
Petticrew \\
\& Roberts \\
(2008); \\
Pickering \& \\
Byrne (2014)
\end{tabular} & $\begin{array}{l}\text { No infor- } \\
\text { mation } \\
\text { provided; } \\
\text { probably } \\
\text { unlimited }\end{array}$ & $\begin{array}{l}\text { No infor- } \\
\text { mation } \\
\text { provided }\end{array}$ & 4 databases & 19 & $\begin{array}{l}\text { Thematic analysis and } \\
\text { synthesis. No references } \\
\text { provided. }\end{array}$ & $\begin{array}{l}\text { Evidence } \\
\text { review }\end{array}$ \\
\hline
\end{tabular}




\begin{tabular}{|c|c|c|c|c|c|c|c|c|c|}
\hline 5 & $\begin{array}{l}\text { Schwendimann, } \\
\text { De Wever, \& Cat- } \\
\text { taneo (2018) }\end{array}$ & $\begin{array}{l}\text { The state-of-the-art of col- } \\
\text { laborative technologies for } \\
\text { initial vocational education: } \\
\text { A systematic literature review }\end{array}$ & $\begin{array}{l}\text { Kitchenham } \\
\text { \& Charters } \\
(2007) ; \\
\text { Aveyard } \\
(2010) \\
\end{array}$ & $\begin{array}{l}\text { No infor- } \\
\text { mation } \\
\text { provided; } \\
\text { probably } \\
\text { unlimited } \\
\end{array}$ & English & 8 databases & 26 & $\begin{array}{l}\text { Descriptive statistic and } \\
\text { thematic analysis (Braun } \\
\text { \& Clarke, 2006) }\end{array}$ & $\begin{array}{l}\text { Scoping } \\
\text { review }\end{array}$ \\
\hline 6 & $\begin{array}{l}\text { Cameron, Stuart, } \\
\text { \& Bell (2017) }\end{array}$ & $\begin{array}{l}\text { Race based inequalities for } \\
\text { Indigenous Australians' par- } \\
\text { ticipation and engagement in } \\
\text { VET: A targeted review of the } \\
\text { research. }\end{array}$ & $\begin{array}{l}\text { No referen- } \\
\text { ces provided }\end{array}$ & $\begin{array}{l}\text { journals: not } \\
\text { reported; } \\
\text { projects: } \\
\text { 2000-2017; } \\
\text { database: } \\
\text { 1998-2016 }\end{array}$ & $\begin{array}{l}\text { No infor- } \\
\text { mation } \\
\text { provided; } \\
\text { probably } \\
\text { English }\end{array}$ & $\begin{array}{l}3 \text { journals }+ \\
\text { research } \\
\text { projects }+ \\
1 \text { database }\end{array}$ & $\begin{array}{l}8 \text { journal } \\
\text { articles; } 11 \\
\text { projects; } 11 ; \\
56 \text { "grey" } \\
\text { publications }\end{array}$ & $\begin{array}{l}\text { Content analysis and } \\
\text { thematic analysis. No } \\
\text { references provided. }\end{array}$ & $\begin{array}{l}\text { Critical } \\
\text { review }\end{array}$ \\
\hline 7 & $\begin{array}{l}\text { Middleton \& } \\
\text { Middleton (2017) }\end{array}$ & $\begin{array}{l}\text { Review of literature on the } \\
\text { career transitions of perfor- } \\
\text { ming artists pursuing career } \\
\text { development }\end{array}$ & $\begin{array}{l}\text { No referen- } \\
\text { ces provided }\end{array}$ & $1980-2015$ & $\begin{array}{l}\text { No infor- } \\
\text { mation } \\
\text { provided }\end{array}$ & $\begin{array}{l}3 \text { journals }+ \\
1 \text { database }+ \\
1 \text { portal }^{8}\end{array}$ & $\begin{array}{l}\text { No infor- } \\
\text { mation } \\
\text { provided }\end{array}$ & $\begin{array}{l}\text { Thematic analysis and } \\
\text { synthesis. No references } \\
\text { provided. }\end{array}$ & $\begin{array}{l}\text { Conceptual } \\
\text { review }\end{array}$ \\
\hline 8 & $\begin{array}{l}\text { Cerda-Navarro, } \\
\text { Sureda-Negre, \& } \\
\text { Comas-Forgas } \\
(2017)\end{array}$ & $\begin{array}{l}\text { Recommendations for con- } \\
\text { fronting vocational education } \\
\text { dropout: A literature review. }\end{array}$ & $\begin{array}{l}\text { Fink (2005); } \\
\text { Petticrew } \\
\text { \& Roberts } \\
\text { (2006); } \\
\text { Littell, } \\
\text { Corcoran \& } \\
\text { Pillai (2008) }\end{array}$ & $\begin{array}{l}\text { published } \\
\text { before } 2014\end{array}$ & $\begin{array}{l}\text { English, } \\
\text { French, and } \\
\text { Spanish }\end{array}$ & 22 databases & 60 & $\begin{array}{l}\text { Inductive formation of ca- } \\
\text { tegories (Taylor \& Bogdan, } \\
\text { 1987) }\end{array}$ & $\begin{array}{l}\text { Evidence } \\
\text { review }\end{array}$ \\
\hline 9 & $\begin{array}{l}\text { Mikkonen, Pylväs, } \\
\text { Rintala, Noke- } \\
\text { lainen, \& Postareff } \\
(2017)\end{array}$ & $\begin{array}{l}\text { Guiding workplace learning } \\
\text { in vocational education and } \\
\text { training: A literature review }\end{array}$ & $\begin{array}{l}\text { Grant \& } \\
\text { Booth (2009) }\end{array}$ & 1995-2015 & English & 2 databases & 18 & $\begin{array}{l}\text { Data extraction matrix. No } \\
\text { references provided. }\end{array}$ & $\begin{array}{l}\text { Evidence } \\
\text { review }\end{array}$ \\
\hline
\end{tabular}

8 Scholars Portal is a digital repository of journals, scholarly articles and books offered by the Ontario Council of University Libraries. 


\begin{tabular}{|c|c|c|c|c|c|c|c|c|c|}
\hline 10 & $\begin{array}{l}\text { Zlatanovic, Hav- } \\
\text { nes, \& Mausetha- } \\
\text { gen (2017) }\end{array}$ & $\begin{array}{l}\text { A research review of nurse } \\
\text { teachers' competencies }\end{array}$ & $\begin{array}{l}\text { Gough, Tho- } \\
\text { mas \& Oliver } \\
\text { (2012b) }\end{array}$ & $2000-2016$ & $\begin{array}{l}\text { English, } \\
\text { Danish, } \\
\text { Swedish \& } \\
\text { Norwegian } \\
\text { languages } \\
\end{array}$ & 7 databases & 25 & $\begin{array}{l}\text { Thematic synthesis (Oliver } \\
\text { \& Sutcliffe, 2012) }\end{array}$ & $\begin{array}{l}\text { Conceptual } \\
\text { review }\end{array}$ \\
\hline 11 & $\begin{array}{l}\text { Tonhäuser \& Bü- } \\
\text { ker (2016) }\end{array}$ & $\begin{array}{l}\text { Determinants of transfer of } \\
\text { training: A comprehensive } \\
\text { literature review }\end{array}$ & $\begin{array}{l}\text { Webster } \\
\text { \& Watson } \\
\text { (2002) }\end{array}$ & 1990-2015 & $\begin{array}{l}\text { No infor- } \\
\text { mation } \\
\text { provided }\end{array}$ & 3 databases & 79 & $\begin{array}{l}\text { Dimensional systematiza- } \\
\text { tion of quantitative studies } \\
\text { based on a theoretical } \\
\text { framework model. Several } \\
\text { references provided. }\end{array}$ & $\begin{array}{l}\text { Scoping } \\
\text { review }\end{array}$ \\
\hline 12 & $\begin{array}{l}\text { Williams, Dodd, } \\
\text { Steele, \& Randall } \\
\text { (2016) }\end{array}$ & $\begin{array}{l}\text { A systematic review of } \\
\text { current understandings of } \\
\text { employability }\end{array}$ & $\begin{array}{l}\text { No referen- } \\
\text { ces provided }\end{array}$ & $1960-2014$ & English & 10 databases & 16 & $\begin{array}{l}\text { Data extraction sheet } \\
\text { and content analysis. No } \\
\text { references provided. }\end{array}$ & $\begin{array}{l}\text { Conceptual } \\
\text { review }\end{array}$ \\
\hline 13 & $\begin{array}{l}\text { Crossman, \& Ca- } \\
\text { meron (2014) }\end{array}$ & $\begin{array}{l}\text { A comparative thematic re- } \\
\text { view of vocational leadership } \\
\text { literature from the USA, } \\
\text { Great Britain and Australia. } \\
\text { Research in post-compulsory } \\
\text { education }\end{array}$ & $\begin{array}{l}\text { No referen- } \\
\text { ces provided }\end{array}$ & 2000-2013 & $\begin{array}{l}\text { No infor- } \\
\text { mation } \\
\text { provided; } \\
\text { probably } \\
\text { English }\end{array}$ & $\begin{array}{l}7 \text { journals } \\
\text { from one } \\
\text { database, } \\
\text { conference } \\
\text { papers from } \\
\text { AVETRA }^{9} \text {, } \\
\text { reports from } \\
\text { NCVER }^{10}\end{array}$ & $\begin{array}{l}\text { number of } \\
\text { identified } \\
\text { articles after } \\
\text { search: } 224, \\
\text { number of } \\
\text { included } \\
\text { articles: unc- } \\
\text { lear (but less } \\
\text { than 224); } 11 \\
\text { conference } \\
\text { papers / } \\
\text { reports }\end{array}$ & $\begin{array}{l}\text { Thematic synthesis. No } \\
\text { references provided. }\end{array}$ & $\begin{array}{l}\text { Conceptual } \\
\text { review }\end{array}$ \\
\hline
\end{tabular}

9 Australian Vocational Education and Training Research Association 10 National Centre for Vocational Education Research 


\section{References}

Arksey, H., \& O’Malley, L. (2005). Scoping studies: Towards a methodological framework. International Journal of Social Research Methodology, 8(1), 19-32. https://doi.org/10.1080/1364557032000119616

Aromataris, E., \& Pearson, A. (2014). The systematic review: An overview. American Journal of Nursing, 114(3), 53-58. https://doi.org/10.1097/01.NAJ.0000444496.24228.2c

Aromataris, E., Fernandez, R., Godfrey, C. M., Holly, C., Khalil, H., \& Tungpunkom, P. (2015). Summarizing systematic reviews: Methodological development, conduct and reporting of an umbrella review approach. International Journal of Evidence-Based Healthcare, 13(3), 132-140. http://doi. org/10.1097/XEB.0000000000000055

Attride-Stirling, J. (2001). Thematic networks: An analytic tool for qualitative research. Qualitative Research, 1(3), 385-405. http://doi.org/10.1177/146879410100100307

Aveyard, H. (2010). Doing a literature review in health and social care: A practical guide (2nd ed.). McGraw-Hill/Open University Press.

Avis, J. (2018). Socio-technical imaginary of the fourth industrial revolution and its implications for vocational education and training: A literature review. Journal of Vocational Education \& Training, 70(3), 337-363. https://doi.org/10.1080/13636820.2018.1498907

Barnett-Page, E., \& Thomas, J. (2009). Methods for the synthesis of qualitative research: A critical review. BMC Medical Research Methodology, 9(59). https://doi.org/10.1186/1471-2288-9-59

Bollen, K., Cacioppo, J. T., Kaplan, R. M., Krosnick, J. A., \& Olds, J. L. (2015). Social, Behavioral, and Economic Sciences Perspectives on Robust and Reliable Science. https://www.nsf.gov/sbe/AC Materials/SBE Robust and Reliable Research Report.pdf

Bondas, T., \& Hall, E. O. (2007). Challenges in approaching metasynthesis research. Qualitative Health Research, 17(1), 113-121. http://doi.org/10.1177/1049732306295879

Booth, A., Noyes, J., Flemming, K., Gerhardus, A., Wahlster, P., van der Wilt G.J., Mozygemba K, Refolo P, Sacchini D, Tummers, M, \& Rehfuess, E. (2016a). Guidance on choosing qualitative evidence synthesis methods for use in health technology assessments of complex interventions. http://www.integrate-hta.eu/downloads

Booth, A., Sutton, A., \& Papaioannou, D. (2016b). Systematic approaches to a successful literature review (2nd ed.). Sage.

Braun, V., \& Clarke, V. (2006). Using thematic analysis in psychology. Qualitative Research in Psychology, 3(2), 77-101. http://dx.doi.org/10.1191/1478088706qp063oa

Cameron, R., Stuart, L., \& Bell, T. (2017). Race based inequalities for Indigenous Australians' participation and engagement in VET: A targeted review of the research. Journal of Vocational Education \& Training, 69(3), 311-332. https://doi.org/10.1080/13636820.2017.1289553

Campbell M., Egan M., Lorenc T., Bond L., Popham F., \& Fenton C. (2014). Considering methodological options for reviews of theory: Illustrated by a review of theories linking income and health. Systematic Reviews, 3(114). https://doi.org/10.1186/2046-4053-3-114

Card, N. A. (2010). Literature review. In N. J. Salkind (Ed.), Encyclopedia of Research Design (pp. 725728). Sage.

Caves, K.M., Baumann, S., \& Renold, U. (2019). Getting there from here: A literature review on vocational education and training reform implementation. Journal of Vocational Education \& Training. Advance online publication. http://doi.org/10.1080/13636820.2019.1698643 
Chankseliani, M., \& Anuar, A. M. (2019). Cross-country comparison of engagement in apprenticeships: A conceptual analysis of incentives for individuals and firms. International Journal for Research in Vocational Education and Training, 6(3), 261-283. https://doi.org/10.13152/IJRVET.6.3.4

Cerda-Navarro, A., Sureda-Negre, J., \& Comas-Forgas, R. (2017). Recommendations for confronting vocational education dropout: A literature review. Empirical Research in Vocational Education and Training, 9, 17. https://doi.org/10.1186/s40461-017-0061-4

Chinedu, C. C., Wan Mohamed W. A., \& Ajah, A. O. (2018). A systematic review on education for sustainable development: Enhancing TVE teacher training programme. Journal of Technical Education and Training, 10(1), 109-125. https://doi.org/10.30880/jtet.2018.10.01.009

Christie, F. (2017). The reporting of university league table employability rankings: A critical review. Journal of Education and Work, 30(4), 403-418. https://doi.org/10.1080/13639080.2016.1224821

Colquhoun, H. L., Levac, D., O’Brien, K. K., Straus, S., Tricco, A. C., Perrier, L., Kastner, M., \& Moher, D. (2014). Scoping reviews: Time for clarity in definition, methods, and reporting. Journal of Clinical Epidemiology, 67(12), 1291-1294. http://doi.org/10.1016/j.jclinepi.2014.03.013

Coughlan, M., \& Cronin, P. (2017). Doing a literature review in nursing, health and social care (2nd ed.). Sage.

Creswell, J. W. (2013). Research design: Qualitative, quantitative, and mixed method approaches (4th ed.). Sage.

Crossman, B., \& Cameron, R. (2014). A comparative thematic review of vocational leadership literature from the USA, Great Britain and Australia. Research in Post-Compulsory Education, 19(4), 393-416. https://doi.org/10.1080/13596748.2014.955374

Demiris, G., Oliver, D. P., \& Washington, K. T. (2019). Behavioral Intervention Research in Hospice and Palliative Care: Building an Evidence Base. Elsevier. https://doi.org/10.1016/C2017-0-01131-X

Emmenegger, P., Graf, L., \& Trampusch, C. (2019). The governance of decentralised cooperation in collective training systems: A review and conceptualisation. Journal of Vocational Education \& Training, 71(1), 21-45. https://doi.org/10.1080/13636820.2018.1498906

Fink, A. (2005). Conducting research literature reviews: From the internet to paper (2nd ed.). Sage.

Fink, A. (2020). Conducting research literature reviews: From the internet to paper (5th ed.). Sage.

Ganann R, Ciliska D, \& Thomas H. (2010). Expediting systematic reviews: methods and implications of rapid reviews. Implementation Science, 5(56). https://doi.org/10.1186/1748-5908-5-56

Gessler, M. (2019). Concepts of Apprenticeship: Strengths, Weaknesses, and Pitfalls. In S. McGrath, M. Mulder M., J. Papier, \& R. Suart (Eds.), Handbook of Vocational Education and Training (pp. 677-709). Springer. https://doi.org/10.1007/978-3-319-94532-3 94

Gough, D., Oliver, S., \& Thomas, J. (2012a). Introducing systematic review. In D. Gough, S. Oliver, \& J. Thomas J, (Eds.), An introduction to systematic reviews (pp. 1-17). Sage.

Gough, D., Thomas, J., \& Oliver, S. (2012b). Clarifying differences between review designs and methods. Systematic Reviews, 1(28), 1-9. https://doi.org/10.1186/2046-4053-1-28

Grant, M. J., \& Booth, A. (2009). A typology of reviews: An analysis of 14 review types and associated methodologies. Health Information and Librairies Journal, 26(2), 91-108. https://doi.org/10.1111/ j.1471-1842.2009.00848.x

Guilbert, L., Bernaud, J.-L., Gouvernet, B., \& Rossier, J. (2016). Employability: Review and research prospects. International Journal for Educational and Vocational Guidance, 16(1), 69-89. https://doi. org/10.1007/s10775-015-9288-4

Hart, C. (2018). Doing a literature review: Release the Research Imagination (2nd ed.). Sage. 
Harzing, A. W. (2019). Two new kids on the block: How do Crossref and Dimensions compare with Google Scholar, Microsoft Academic, Scopus and the Web of Science? Scientometrics, 120(1), 341349. https://doi.org/10.1007/s11192-019-03114-y

Haug, E. H., Plant, P., Valdimarsdóttir, S., Bergmo-Prvulovic, I., Vuorinen, R., Lovén, A., \& Vilhjálmsdóttir, G. (2019). Nordic research on educational and vocational guidance: A systematic literature review of thematic features between 2003 and 2016. International Journal for Educational and Vocational Guidance, 19(2), 185-202. https://doi.org/10.1007/s10775-018-9375-4

Hökkä, P., Vähäsantanen, K., \& Paloniemi, S. (2019). Emotions in Learning at Work: A Literature Review. Vocations and Learning. Advance online publication. https://doi.org/10.1007/s12186-01909226-Z

Hughes, D., Mann, A., Barnes, S. A., Baldauf, B., \& McKeown, R. (2016). Careers education: International literature review. Education Endowment Fund. https://www.educationandemployers.org/ research/careers-education-international-literature-review/

Imenda, S. (2014). Is there a conceptual difference between theoretical and conceptual Frameworks? Journal of Social Sciences, 38(2), 185-195. https://doi.org/10.1080/09718923.2014.11893249

Jesson, J., Matheson, L., \& Lacey, F. M. (2011). Doing your literature review: Traditional and systematic techniques. Sage.

Kayser, H., \& Ziegler, B. (2014). Erkenntnisse zur Gestaltung der Berufsorientierung Jugendlicher an Sekundarschulen. Ergebnisse einer integrativen Review und ihre Implikationen. Zeitschrift für Berufs- und Wirtschaftspädagogik, 110(2), 216-234.

Kazrin, A., Durac, J., \& Agteros, T. (1979). Meta-meta analysis: A new method for evaluating therapy outcome. Behaviour Research and Therapy, 17(4), 397-399. https://doi.org/10.1016/00057967(79)90011-1

Kitchenham, B., \& Charters, S. (2007). Guidelines for performing systematic literature reviews in software engineering, Technical report, Keele University (UK).

Krezmien, M., Camacho, K., \& Travers, J. (2017). Using methodological reviews and meta-analyses to identify current best practices in school-based counseling. In J. C. Carey, B. Harris, S. M. Lee, \& O. Aluede (Eds.), International Handbook for Policy Research on School-Based Counseling (pp. 105-120). Springer. https://doi.org/10.1007/978-3-319-58179-8 8

Langlois, E. V., Straus, S. E., Mijumbi-Deve, R., Lewin, S., \& Tricco, A. C. (2017). The need for rapid review to inform health policy and systems. In A. C. Tricco, E. V. Langlois, \& S. E. Straus (Eds.), Rapid reviews to strengthen health policy and systems: A practical guide (pp. 1-19). World Health Organization.

Levac, D., Colquhoun, H., \& O’Brien, K. K. (2010). Scoping studies: Advancing the methodology. Implementation Science, 5(69). https://doi.org/10.1186/1748-5908-5-69

Littell, J. H., Corcoran, J., \& Pillai, V. (2008). Systematic reviews and meta-analysis. Oxford University Press. http://doi.org/10.1093/acprof:oso/9780195326543.001.0001

MacLure, M. (2005). Clarity bordering on stupidity: Where's the quality in systematic review? Journal of Education Policy, 20(4), 393-416. http://doi.org/10.1080/02680930500131801

McGrath, S., Ramsarup, P., Zeelen, J., Wedekind, V., Allais, S., Lotz-Sisitka, H., Monk, Openjuru, G., \& Russon, J.-A. (2019). Vocational education and training for African development: A literature review. Journal of Vocational Education \& Training. Advance online publication. http://doi.org/10. $\underline{1080 / 13636820.2019 .1679969}$ 
Middleton, J. C., \& Middleton, J. A. (2017). Review of literature on the career transitions of performing artists pursuing career development. International Journal for Educational and Vocational Guidance, 17(2), 211-232. https://doi.org/10.1007/s10775-016-9326-x

Mikkonen, S., Pylväs, L., Rintala, H., Nokelainen, P., \& Postareff, L. (2017). Guiding workplace learning in vocational education and training: A literature review. Empirical Research in Vocational Education and Training, 9(9). https://doi.org/10.1186/s40461-017-0053-4

Moher D., Cook D. J., Eastwood S., Olkin I., Rennie D., \& Stroup D. F. (1999). Improving the quality of reporting of meta-analysis of randomized controlled trials: The QUOROM statement. The Lancet, 354(11), 1896-1900. https://doi.org/10.1016/S0140-6736(99)04149-5

Moher D, Liberati A, Tetzlaff J, Altman D. G., \& The PRISMA Group (2009). Preferred Reporting Items for Systematic Reviews and Meta-Analyses: The PRISMA Statement. PLoS Med 6(7), Article e1000097. https://doi.org/10.1371/journal.pmed.1000097

Munn, Z., Stern, C., Aromataris, E., Lockwood, C., \& Jordan, Z. (2018). What kind of systematic review should I conduct? A proposed typology and guidance for systematic reviewers in the medical and health sciences. BMC Medical Research Methodology, 18(5). https://doi.org/10.1186/s12874017-0468-4

Oakley, A. (2002). Social science and evidence-based everything: The case of education. Educational Review, 54(3), 277-286. https://doi.org/10.1080/0013191022000016329

Oliver, S., \& Sutcliffe, K. (2012). Describing and analysing studies. In D. Gough, S. Oliver, \& J. Thomas (Eds.), An introduction to systematic reviews (pp. 135-153). Sage.

Paré, G., Trudel, M.-C., Jaana, M., \& Kitsiou, S. (2015). Synthesizing information systems knowledge: A typology of literature reviews. Information \& Management, 52(2), 183-199. https://doi. org/10.1016/j.im.2014.08.008

Peters, M. D. J., Godfrey, C. M, Khalil, H., McInerney P., Parker, D., \& Soares C. B. (2015). Guidance for conducting systematic scoping reviews. International Journal of Evidence-Based Healthcare, 13(3), 141-146. https://doi.org/10.1097/XEB.0000000000000050

Petticrew, M., \& Roberts, H. (2006). Systematic reviews in the social sciences: A practical guide. Print Version. Wiley-Blackwell.

Petticrew, M., \& Roberts, H. (2008). Systematic reviews in the social sciences: A practical guide. Online Version. Wiley-Blackwell.

Pickering, C., \& Byrne, J. (2014). The benefits of publishing systematic quantitative literature reviews for $\mathrm{PhD}$ candidates and other early-career researchers. Higher Education Research and Development, 33(3), 534-548. https://doi.org/10.1080/07294360.2013.841651

Rovira, C., Codina, L., Guerrero-Solé, F., \& Lopezosa, C. (2019). Ranking by relevance and citation counts, a comparative study: Google scholar, microsoft academic, WoS and scopus. Future Internet, 11(9), 202. https://doi.org/10.3390/fi11090202

Salvà, F., Pinya, C., Álvarez, N., \& Calvo, A. (2019). Dropout prevention in Secondary VET from different learning spaces: A social discussion experience. International Journal for Research in Vocational Education and Training, 6(2), 153-173. https://doi.org/10.13152/IJRVET.6.2.3

Sayre, F., \& Riegelman, A. (2018). The reproducibility crisis and academic libraries. College and Research Libraries, 79(1), 2-9. https://doi.org/10.5860/crl.79.1.2

Schwendimann, B. A., De Wever, B., Hämäläinen, R., \& Cattaneo, A. A. P. (2018). The State-of-the-Art of Collaborative Technologies for Initial Vocational Education: A Systematic Literature Review. 
International Journal for Research in Vocational Education and Training, 5(1), 19-41. https://doi. org/10.13152/ijrvet.5.1.2

Small, L., Shacklock, K., \& Marchant, T. (2018). Employability: A contemporary review for higher education stakeholders. Journal of Vocational Education \& Training, 70(1), 148-166. https://doi.or $\mathrm{g} / 10.1080 / 13636820.2017 .1394355$

Snyder, H. (2019). Literature review as a research methodology: An overview and guidelines. Journal of Business Research, 104, 333-339. https://doi.org/10.1016/j.jbusres.2019.07.039

Spours, K., Hodgson, A., Grainger, P., \& Smith, D. (2019). Area-based reviews and their aftermath: Moving to a post-incorporation model for further education in England?, Journal of Vocational Education \& Training. Advance online publication. https://doi.org/10.1080/13636820.2019.1607 $\underline{534}$

Strandberg, T., \& Simpson, G. K. (2019). An audit of literature reviews published in Australian social work (2007-2017). Australian Social Work. Advance online publication. https://doi.org/10.1080/0 312407X.2019.1571619

Taylor S. J., \& Bogdan, R. (1987). Introducción a los métodos cualitativos de investigación: La búsqueda de significados. Ediciones Paidós Ibérica,

Tonhäuser, C., \& Büker, L. (2016). Determinants of transfer of training: A comprehensive literature review. International Journal for Research in Vocational Education and Training, 3(2), 127-165. https://doi.org/10.13152/ijrvet.3.2.4

Toye, F., Seers, K., Allcock, N., Briggs, M., Carr, E., \& Barker, K. (2014). Meta-ethnography 25 years on: Challenges and insights for synthesising a large number of qualitative studies. BMC Medical Research Methodology, 14(80). https://doi.org/10.1186/1471-2288-14-80

Tricco, A. C., Lillie, E., Zarin, W., O'Brien, K., Colquhoun, H., Kastner, M., Levac, D., Ng, C., Sharpe, J. P., Wilson, K., Kenny, M., Warren, R., Wilson, C., Stelfox, H. T., \& Straus, S. E. (2016). A scoping review on the conduct and reporting of scoping reviews. BMC Medical Research Methodology, 16(15). https://doi.org/10.1186/s12874-016-0116-4

Wang, J. (2019). Demystifying Literature Reviews: What I have learned from an expert? Human Resource Development Review, 18(1), 3-15. https://doi.org/10.1177/1534484319828857

Webster, J., \& Watson, R. (2002). Analyzing the past to prepare for the future: Writing a literature review. Management Information Systems Quarterly, 26(2), xiii-xxiii. https://www.jstor.org/stable/4132319

Williams, S., Dodd, L. J., Steele, C., \& Randall, R. (2016). A systematic review of current understandings of employability. Journal of Education and Work, 29(8), 877-901. https://doi.org/10.1080/13 $\underline{639080.2015 .1102210}$

Zlatanovic, T., Havnes, A., \& Mausethagen, S. (2017). A Research Review of Nurse Teachers' Competencies. Vocations and Learning, 10(2), 201-233. https://doi.org/10.1007/s12186-016-9169-0 


\section{Biographical Notes}

Michael Gessler, Dr phil., Dr h.c., is a Full Professor of Vocational Education and Training at the Institute Technology and Education (ITB), University of Bremen, Germany. His research focus is on innovations and transfer of innovations in vocational education and training.

Christine Siemer, M.A., is a research assistant and doctoral researcher at the Institute Technology and Education (ITB), University of Bremen, Germany. Her research focus is on digitalization and internationalization of vocational education and training. 